
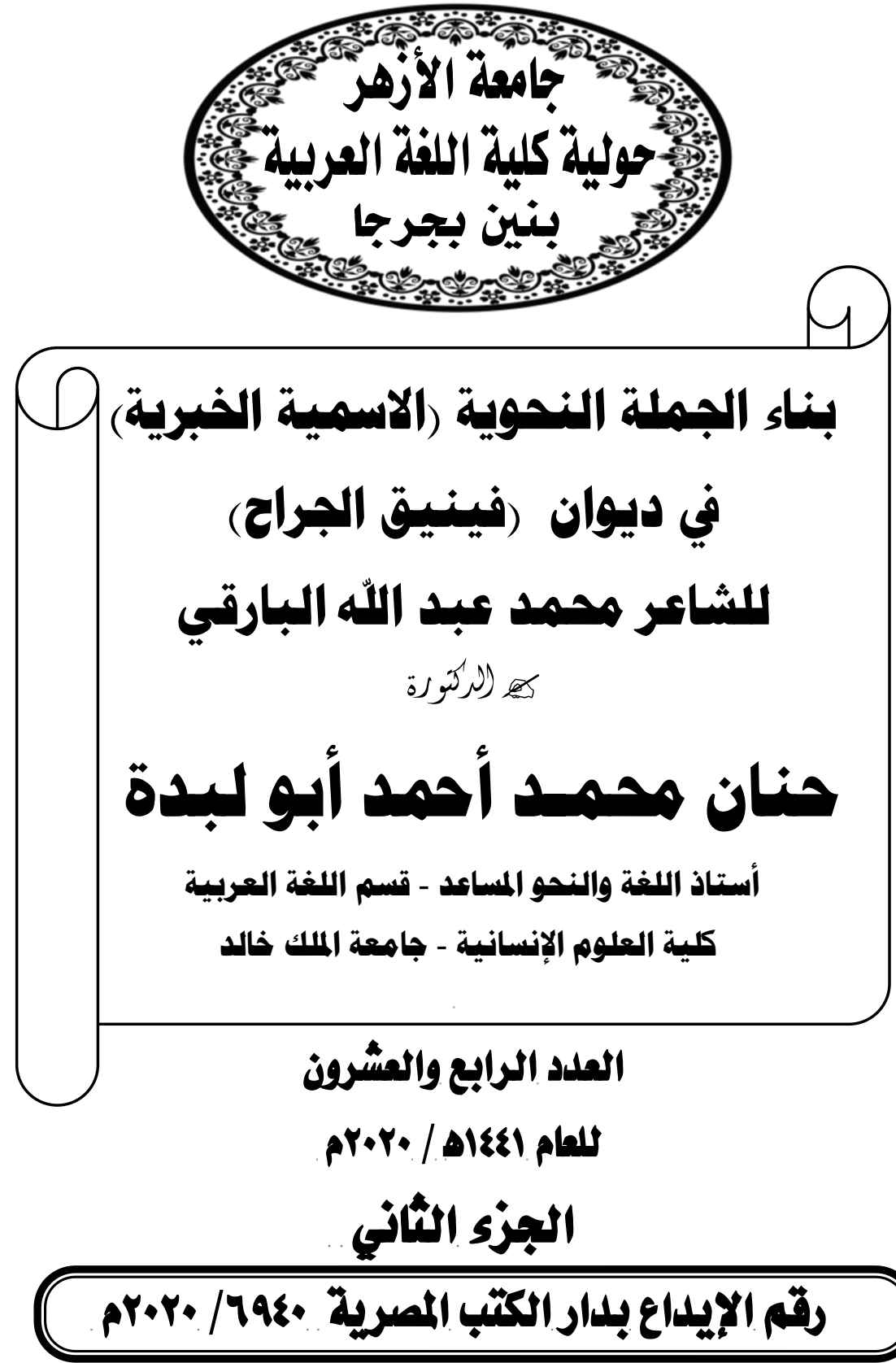

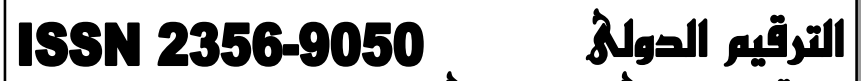

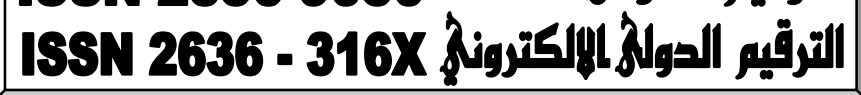




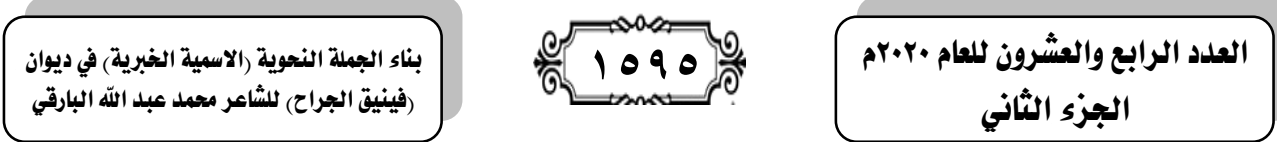

هِن

$$
\text { ( شكر وتقدير) }
$$

$$
\text { (الباحثة تود شكر }
$$

\section{جاومة الثالد}

على الدعم الإداري والفني

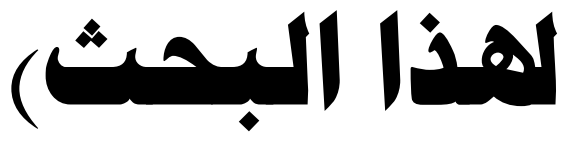




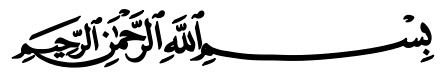

بناء الجملة النحوية (الاسمية الخبرية) في ديوان (فينيق الجراح)

لالشاءر مهمد عبد الاله البارتي في ايوان

حنان همهـد أحمد أبو لبدة

قسم اللغة والنحو - قسم اللغة العربية - كلية العلوم الإنسانية- جاهعة الملك خالد ـ المملكة العربية السعودية Hanan.205@bau.edu.jo : البريد الإلكتروني

يمثِّل ديوان محمـد عبد الله البارقي تراثًا إبداعيًا متميزًا يضاف إلى

التراث الإبلاعي العربي المميز المنظوم بالفصحى. وبما أن لغتنا الفصحى تعدّ ألمئ من أهم عناصر هوية أمتنا العربية فمن واجبنا تتبع أساليبها ودراستها، في التراث الأي كتب بها، ومن هنا جاءت أهمية البحث؛ فهو يمثل دراسة تطبيقية تبيّن استعمال الشاعر البارقي للجملة الاسمية الخبرية في ديوان (فينيق

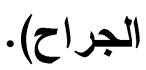

كما تتجلى أهميته في معرفة مدى موافقة استعماله للجملة، مع ما أصَََّهُ

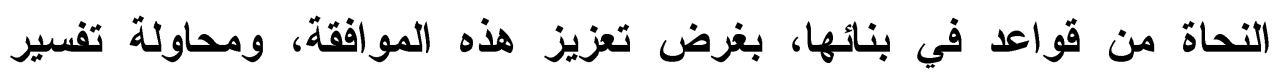
الاستعمالات المخالفة إن وجدت؛ ولمد الجسور بين اللغة المعاصرة، ولغة المتقدمين؛ للحفاظ على لغة التراث قوية في الاستخدام المعاصر. كما يسهم هذا البحث في تعزيز المبدعين من الشعراء الثباب الأين يعبرون عن تجاربهم الثعرية بالفصحى بصورة مثلى، الشعراء العرب على وجه العموم، وشعراء منطقة عسير على وجه الخصوص.

الكلمات الفتـاحيـة : الجملة النحوية ، فينيق الجراح ، بناء الجملــة ، البــارقي ،

در اسة نحوية .

\section{0}


(Syntactic Syntax (Nominal) in Diwan (Phinic of Jarrah

Poet Mohammed Abdullah Al-Barqi

Hanan Mohammed Ahmed Abu Libdeh

Department of Language and Grammar - Department of Arabic Language - College of Humanities - King Khalid University - Kingdom of Saudi Arabia

Email: Hanan.205@bau.edu.jo

\section{$\underline{\text { Abstract }}$}

Diwan Muhammad Abdullah Al-Barqi represents a distinctive creative heritage that adds to the distinctive Arab creative heritage organized by Al-Fusha. Since our classical language is considered one of the most important elements of the identity of our Arab nation, it is our duty to follow its methods and study it, in the heritage in which it was written, and hence the importance of the research; it represents an applied study that shows the use of the baroque poet in the nominal, news sentence in Diwan (Phenic of Jarrah).

Its importance is also evident in knowing the extent of its use of the sentence, along with the rules of the grammarians in its construction, in order to enhance this approval, and trying to explain the contrary uses if any; and to build bridges between the contemporary language and the language of the applicants; to maintain the language of heritage strong in contemporary use. This research also contributes to promoting the creators of young poets who express their poetic experiences with classical Ideal, Arab poets in general, and poets in the Asir region in particular.

Keywords: grammatical sentence, Phoenician, surgeon, sentence structure, Barqi, grammatical study.

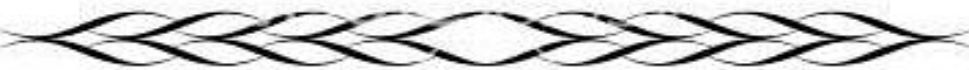




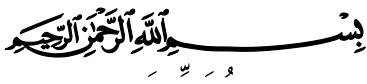

هقدمة:

عبَّر الثشاعر محمــــ عبد الله البارقي عن فكـره ومشـــاعره، بلغتــهـ

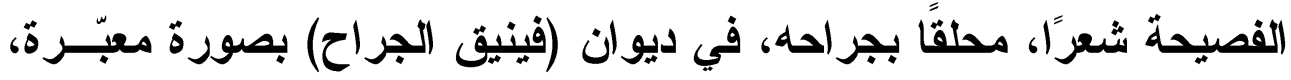

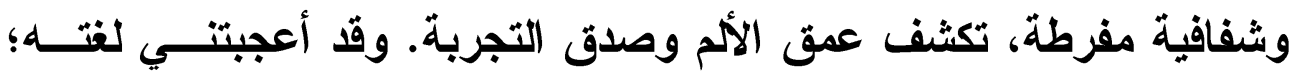
مفردات وتر اكيب، وأساليب نحوية وبلاغية، ور أيت ديو انه يمثِّل تراثًا إبداعيًا متميزًا يضاف إلى التزاث الإبداعي العربي المميز المنظوم بالفصحى. وبمــا

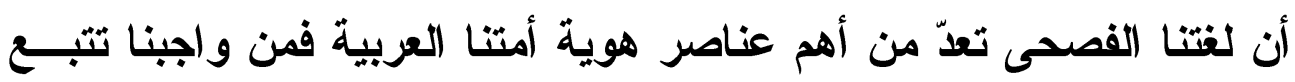

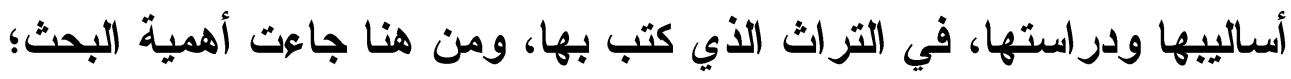

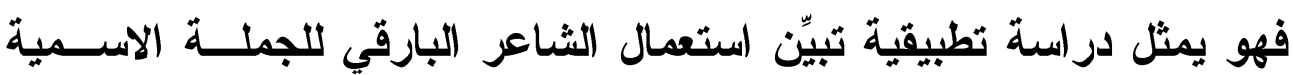
الخبرية في ديوان (فينيق الجراح).

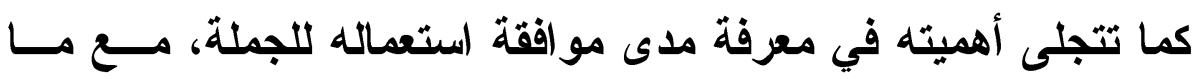

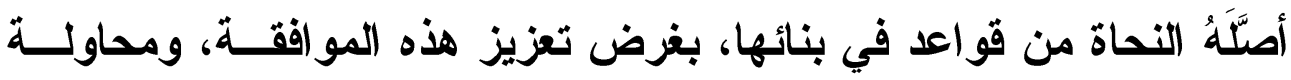

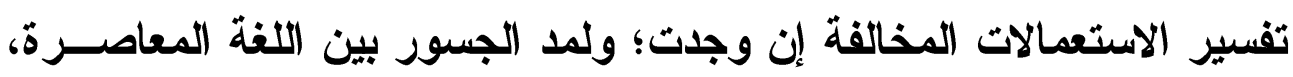

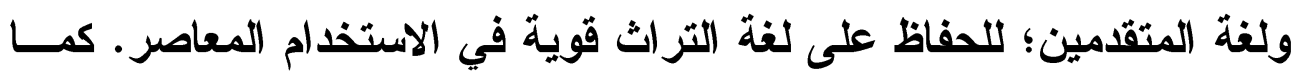

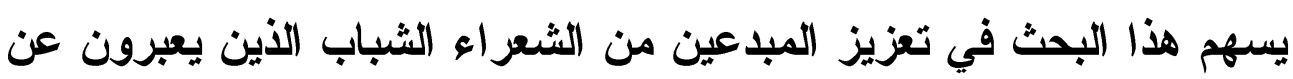

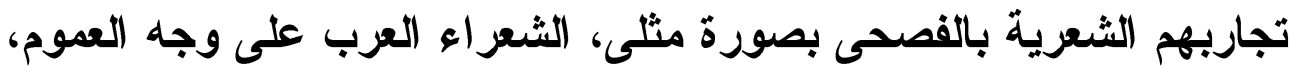
وشعر اء منطقة عسير على وجه الخصوص.

وكنت عزمت على دراسة الجملة النحوية (الاسمية والفعلية) الخبريــة

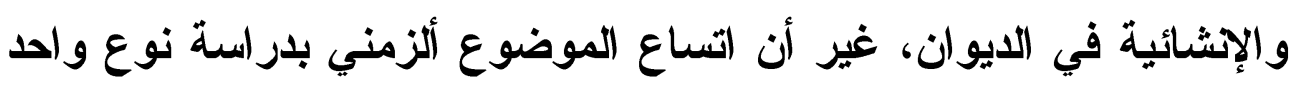

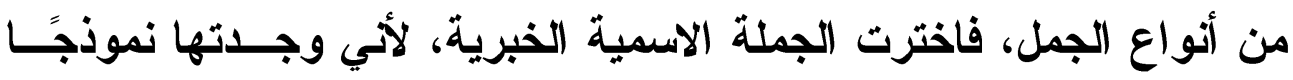

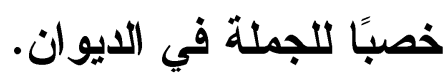


واتبعت المنهج الوصفي التحليلي ، وذلك بعـرض الأمـــاط الرئيســة للجملة الاسمية الخبرية وتقسيم هذه الأنماط إلى صور فرعية، كما أصّـــها النحاة، وتطبيق هذه الأماط النحوية، على الجملة الاسمية الخبرية الــواردة

$$
\text { في ديوان (فينيق الجراح). }
$$

\section{وحسب هقتضيات البمث تضمن المتويات الآتية:}

ا.نبذة عن الشاعر محمـــ البارقيـي.

Y .مفهوم الجملة النحوية عند النحويين العرب قديمًا وحديثًا.

r.أنماط الجملة الاسمية الخبرية، كما اصّّها النحويون، وتطبيـث هـــه

$$
\begin{aligned}
& \text { الأماط على الجمل في ديوان (فينيق الجراح). } \\
& \text { ع ـخلاصة البحث. } \\
& \text { ه هاتمة تتضمن نتائج البحث. } \\
& \text { *نبذة عن الشاعر هممسد البارقي) }
\end{aligned}
$$

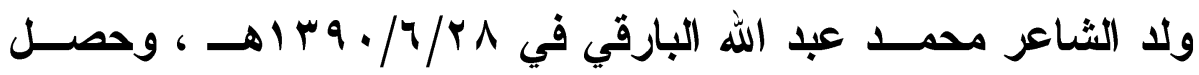
على بكالوريوس لغة عربية في جامعة الملك عبد العزيــز ويعمـل معلمَّـا بمحافظة بارق، وهو عضو في نادي أبها الأدبي، وعضــو نـادي عسـير للتصوير الفوتوغر افي.

له ديوان شعر مطبوع في عام سا ـ بام بعنوان (فينيق الجراح). * السيرة الأتية للشاعر محمد البارقي، نادي أبها الأدبي • 
البملة لغة:

الجملة في اللغة، من جمل الثيء أي جمعه، والجمل الجماعـة مـن الناس، وقيل لكل جماعة غير منفصلة جملة .....، و الجملة واحدة الجمـل،

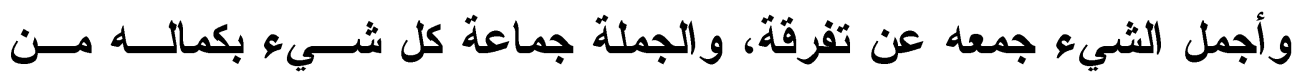

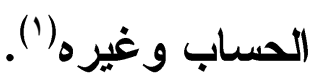
الجملة في الاصطلاح عند النحويين القدهماء: لم يستخدم سييويه (ت . 11 اهــ) مصطلح الجملة، على الوجــه الـــي

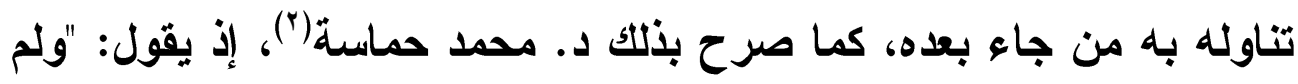

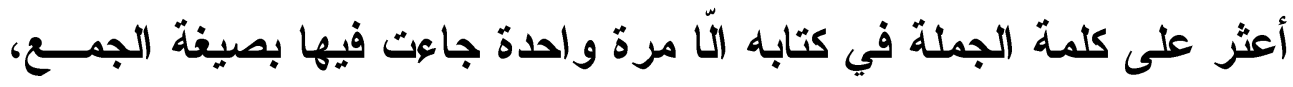

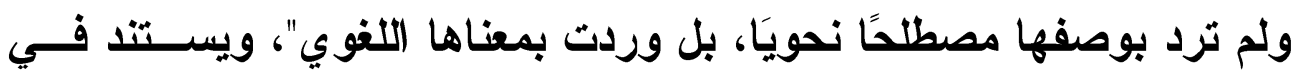

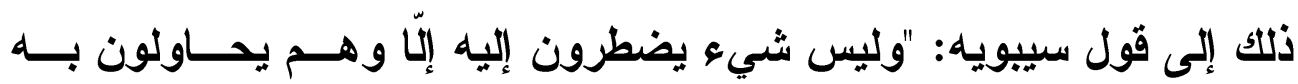

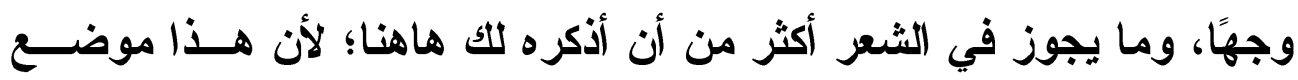

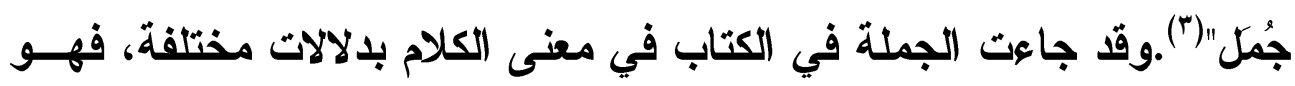

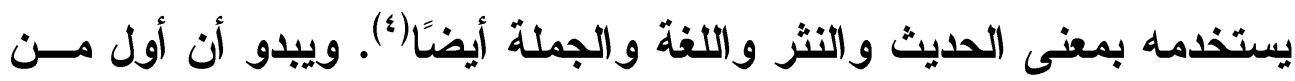

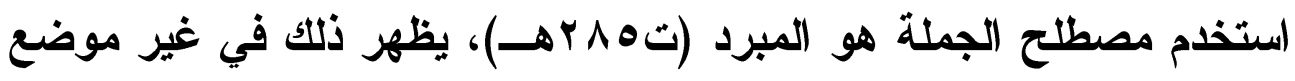

في كتاب المقتضب(ْ).

من ذلك قوله عند إثارته لباب الفاعل يقول:" وهو رفع، وذلك قولتك:

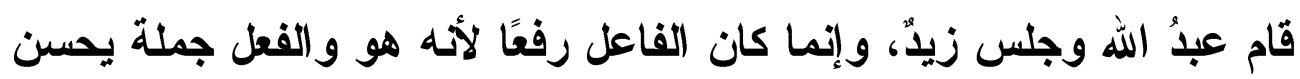

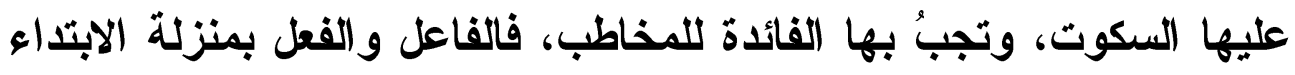
والخبر، إذا قلت: قام زيد، فهو بمنزلة قولك: القائم زيديُ"("). 
وقد ورد مصطلح الجمل المفيدة عند تلميذه ابن السراج (ت 1 آهــ)،

قائًا: " والجمل المفيدة على ضربين: إما فعل وفاعل، و إما مبتدأ وخبر" (v)، ولأن الكلام يتصل بالجملة اتصالًا وثيقًا، ويرتبط بها بعلاقات وشــيجة فــإن المتأخرين من النحاة شظلوا أنفسهم بالتفريق بينهما، فاتقسموا لذلك فريقين:

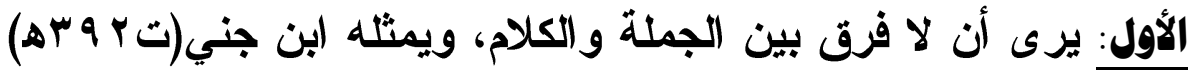

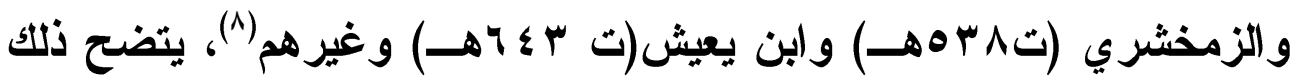
في معرض حديثهم عن الكلام والجملة، وفي ذلك يقول ابــن جنــي معرفًا الكلام: "كل لفظ مستقل بنفسه، مفيد لمعناه، وهو الأي يســميه النحويــون

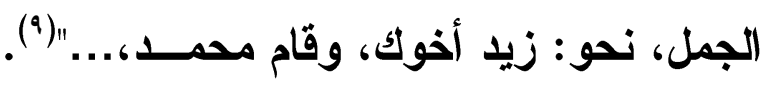

وتتضح كذلك المساواة بين المصطلحين في قـول الزمخثــري فـي المفصل: "إن الكلام هو المركب من كلمتين أسندت إحداهما إلـى الأخــرى، وذلك لا يتأتى إلا في اسمين، كقولك: زيدٌ أخوك، وبشر صاحبك، أو في فعل واسم، نحو قوللك: ضرب زيدّ، وانطلق بكر، ويسمى الجملة"(·'). ويؤيد هذه المساواة بين المصطلحين ابن يعيش في قوله: "اعلم أن الكلام عند النحويين عبارة عن كل لفظ مستقل بنفسه، مفيدٍ لمعناه، ويسمى الجملة، نحو: يزيـــ

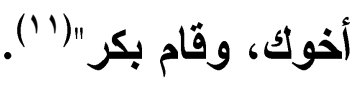

الثـاني: يرى أن الجملة أعمّ من الكلام، ولا يشترط فيها الفائدة، فكـلـ كلام جملة، والعكس ليس صحيـحًا، وقال بـــللك أكثر النحاة، منهم الرضي

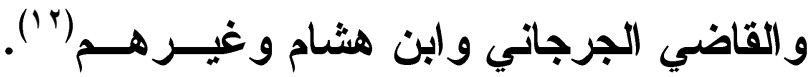

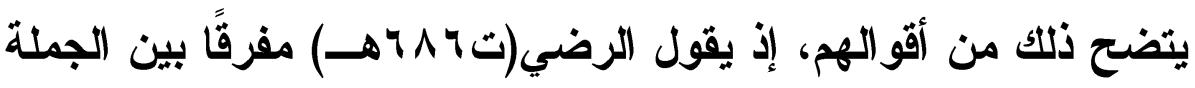
والكلام : " الفرق بين الجملة والكلام أن الجملة ما تضمن الإسناد الأصــلي،

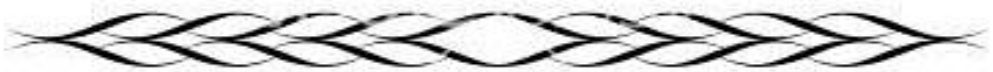


سواء كاتت مقصودة لذاتها أوثًا، كالجملة التي هي خبر المبتدأ، أو سائر ما

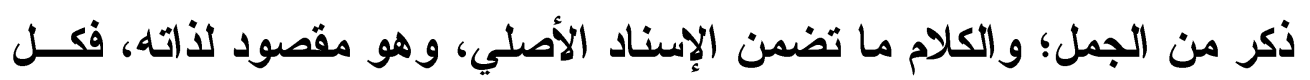

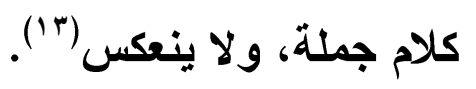
ويظهر ذلك في قول الجرجاني(ت 1 1 1هـ) في تعريف الجملة: " عبارة

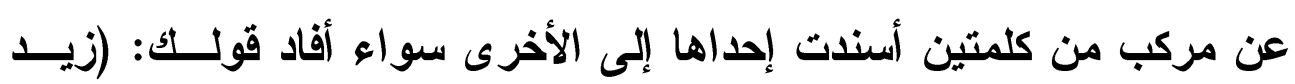

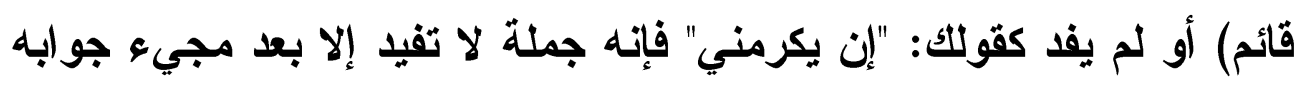

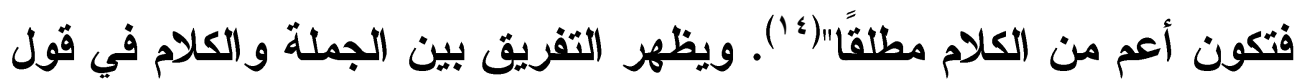

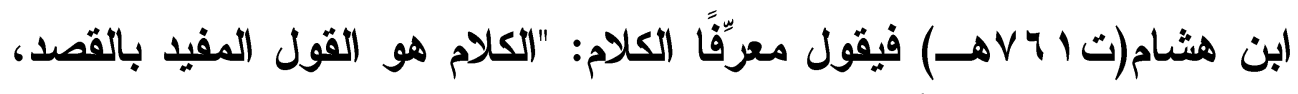

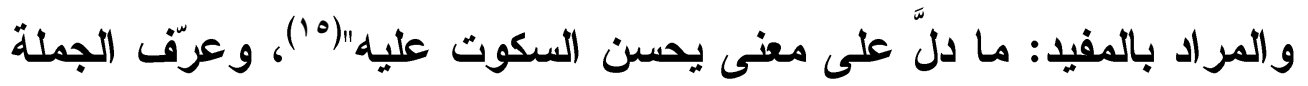

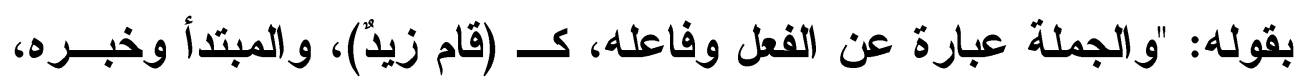

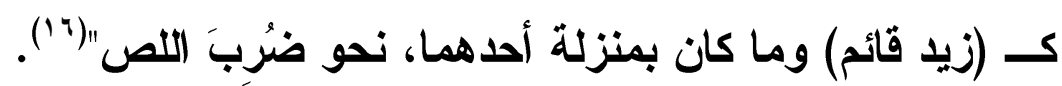
يتبين من قوله أن الكلام ليس مرادفًا للجملـــة؛ لأن شــرطه الإفــادة

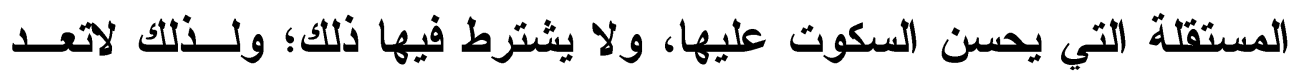

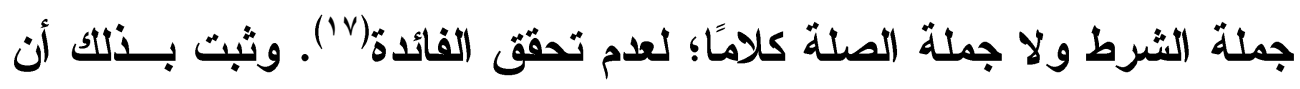

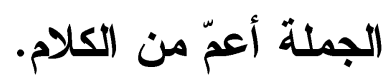

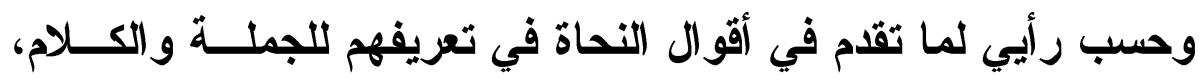

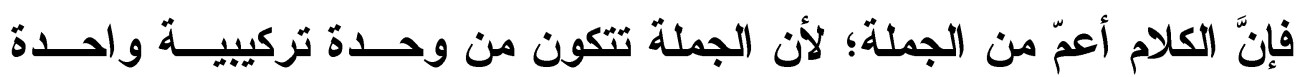

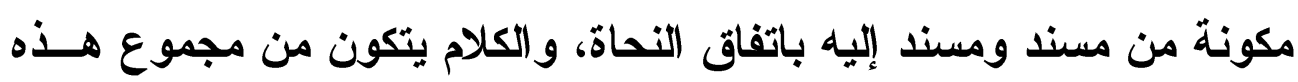

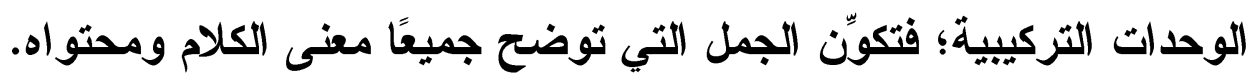




\section{هفهوم البملة عند علماك النحو المهدثين:}

إذا تتبعنا مفهوم الجملة عند النحاة العرب المحدثين نجدهم لا يتفةـون

على مصطلح موحد للجملة، إذ يقول الدكتور إبراهيم أنيس معرفًا الجملـــة: "إن الجملة في أقصر صورها هي أقل قدر من الكلام يفيــــ الســـامع معنــى مستقلًا بنفسه سواء تركب هذا القدر من كلمة واحدة أو أكثر، فـــإذا ســأل القاضي أحد المتهمين قائًا: " من كان معك وقت ارتكاب الجريمةٌ؟ فأجــاب (زيد) فقد نطق هذا المتهم بكلام مفيد في أقصر صورة"(^"). ويعرف الاكتور مهدي المخزومي الجملة قائلًا: "والجملة فـي أقصــر صورها هي أقل قار من الكلام يفيد السامع معنى مستقلتًا بنفســه، ولــيس لازمًا أن تحتوي العناصر المطلوبة كلها، قد تخلو الجملة من المســنـ إليــه لفظًا أو من المسند لوضوحه وسهولة تقديره(9"). ويذا نجد د.أنيس و د.المخزومي يتفقان في أن الجملة ينبغي أن تحقق

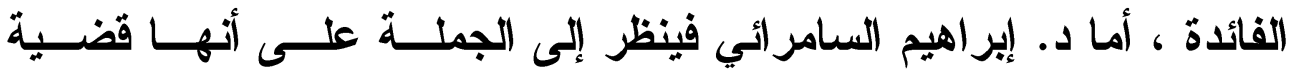

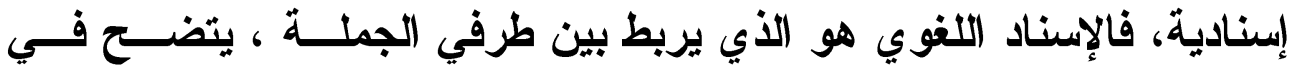
قوله: " ولن نخرج في بحثنا في مسألة الجملة عن الإسناد، فالجملة كيفـــا كاتت اسمية أو فعلية قضية إسنادية، فالإسناد اللغوي علاقة وارتبــاط مسن

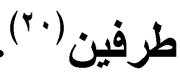

ويذهب أحد الباحثين إلى أن الجملة كل إسناد تضمن فائدة تامــة مــع متعلقاته ومقيداته كافّة ، وبذا يخرج منها التركيب الإسنـادي، وكـلـ مركــب إسنادي له موقع من الإعراب أو ليس له، وذلك لأنهما لم يتضــــا الفائــدة التامة وإن توفر الإسناد(با"). وبذلك نجده يشترط في الجملة إفادتها لمعنسى 
تام، بصرف النظر عن تحقق العلاقات الإسنادية فيها. وفيما أرى فإن تحقق الفائدة في المعنى، ووضوحه لاى السامع مع مقتضيات تكوين الجملة؛ ولذا لـأ

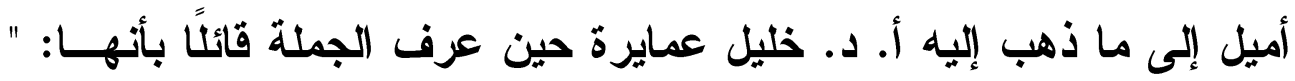

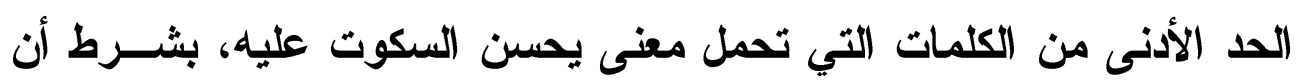
تندرج في نمط من أنماط البناء الجملي في اللغة العربية(r).

\section{أقسام البملة العربية:}

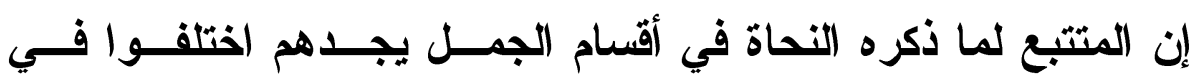

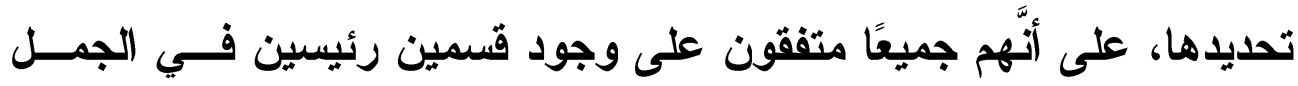

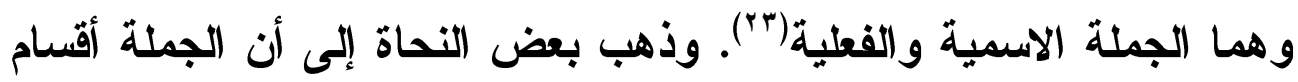

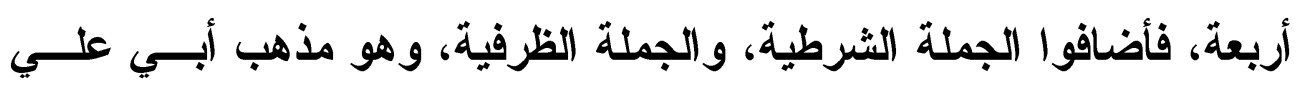

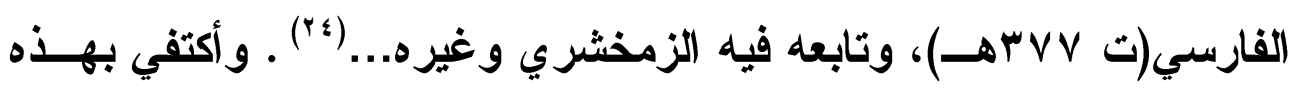

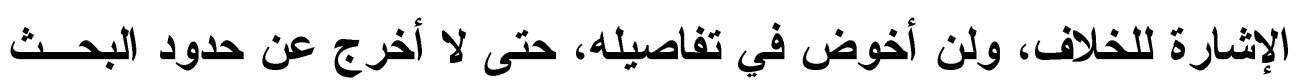

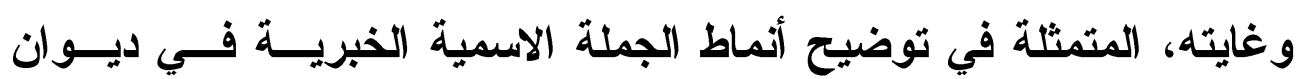
(فينيق الجراح).

\section{الجملة الاسمية الخبرية:}

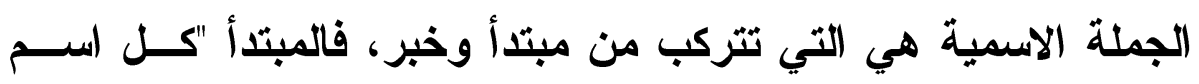

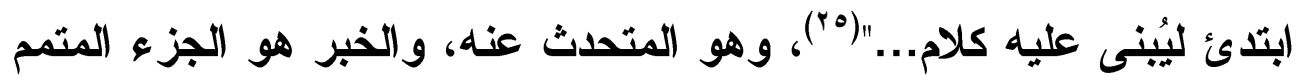

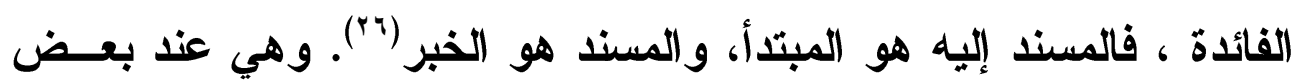

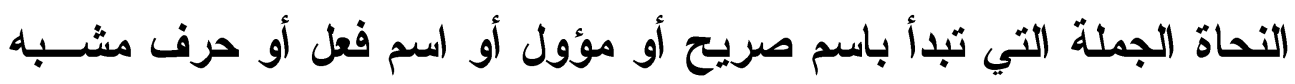

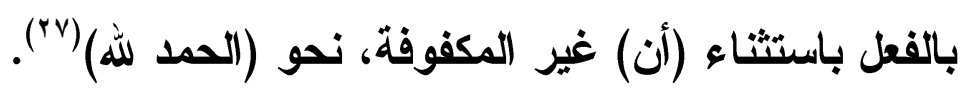




\section{وسيقوم البحث بتتبع الجمهلة الاسمية بأنواءها.}

أما الجملة الخبرية فهي التي إن طابقت نسبة الجملة فيها الواقع كاتت

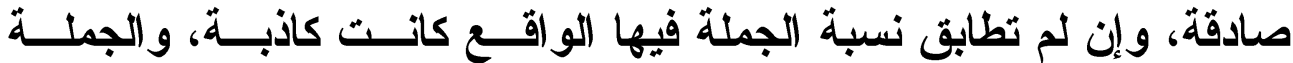
الإنشائية هي التي لا تحتمل الصدق أو الكذب لأتــهـ، ولا يصـــَّ أن يقــال لقائلها إنه كاذب أو صادق لعدم تحقق مدلوله في الخارج وتوققه على النطق به(^) ، ويذا فإن الجملة الخبرية تقاس بمقياس الصدق والكذب.

وبعد قراعتي لايوان فينيق الجراح لمست الصدق في أفكــار الثـــاعر ومشاعره وانفعالاته تجاه الكون والناس والحياة، ولا سيّما أنه يعبّـر عــن أحزانه، التي تكثف صدقه مع ذاته، ومع تفاعلاته مع كل ما يحيط به، وقا وجدت الجملة (الاسمية الخبرية) في ديوانه من أكثر الجمل وضــوحًا فـي التعبيز عن هذا الحزن. وإن كاتت دراستي تتصبٌٌ على دراسة الجملة مــن الشق النحوي كما ذكر.

\section{(الجمملة الاسمية المثبتة)}

\section{أولاً: ها وقع فيها المبتدأ همرفة}

"قأما المبتدأ فلا يكون إلا معرفة، أو ما قارب المعرفة من النكرات"(ج؟؛ وذلأك لأنه محكوم عليه، والحكم على الشيء لا يكون الّا بعد معرفته.

والترتيب الشائع للمعارف أن " أقواها بعد لفظ الجلالة وضــميره هــو

ضمير المتكلم ثم المخاطب ثم العلم وهو درجات متفاوتة القوة فــي درجــة التعريف..... ثم ضمير الغائب الخالمي من الإبهام....، ثــم اســـم الإثـــارة، والمنادى (النكرة المقصودة) وهما في درجة واحدة؛ لأن التعريف بكل منهما

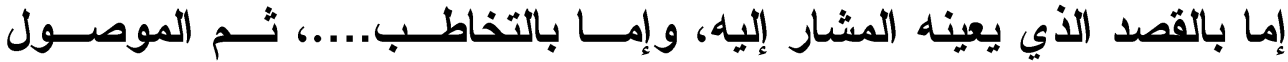

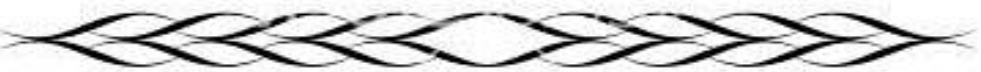


و المعرف بأل وهما في درجة واحدة، أما المضاف إلى معرفة فإنه في درجة

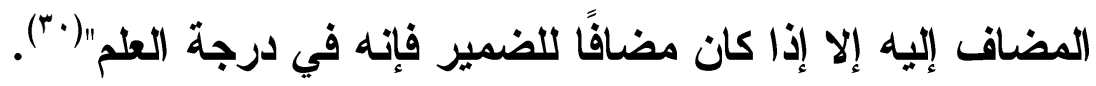
وسأتبع في ترتيب الأنماط و الفروع هذا الترتيب لأنواع المعرفة كمـ قرر النحاة.

\section{الأول: المبتدأ معرفة والخبر نكرة}

يعدّ هذا النمط من أفضل أنماط الجملة الاسمية، كما يتضح من أقــوال

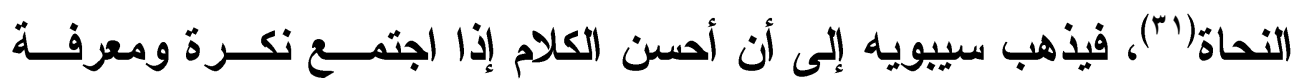

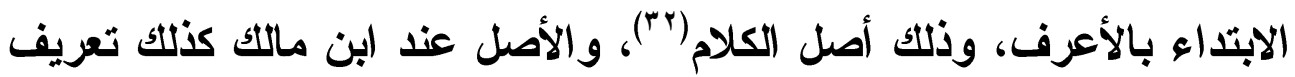

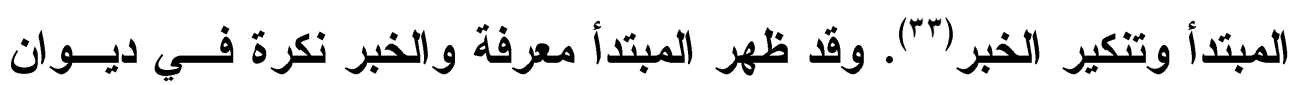
فينيق الجراح في صور عدة على النحو الآتي: أ- المبتدأ معرفة (علم)، والخبر نكرة، ظهر في موضعين:

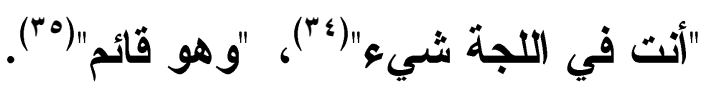

ب- المبتدأ معرفة (مضاف إلى ضمير)، والخبر نكرة ظهـر فـي (ثلاثــة)

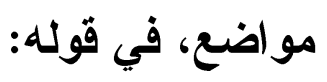

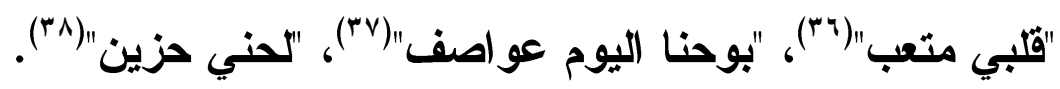
ت- المبتدأ معرفة (مضاف إلى ضمير المتكلم)، والخبر نكـــة ظهـر فــي (سبعة) مو اضع في قوله:

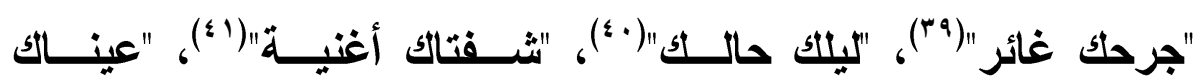

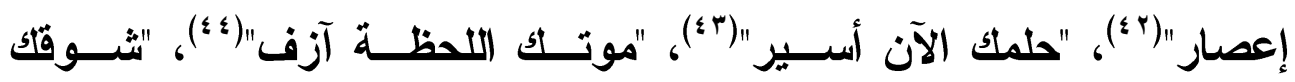




بناء الجملة النحوية (الاسمية الخبرية) في ديوان

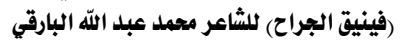

\section{(19.V}

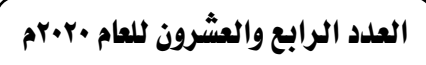
الجزء الثاني

ث- المبتدأ معرفة (معرف بأل)، والخبر نكرة ظهـر فــي (أربعـة عثــر) موضعًا:

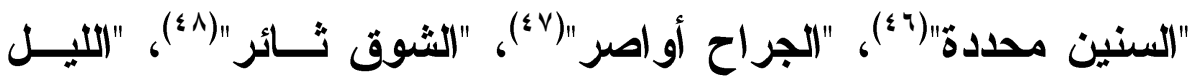

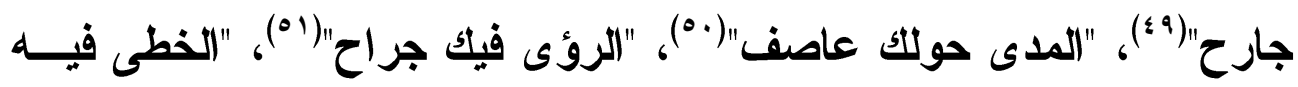

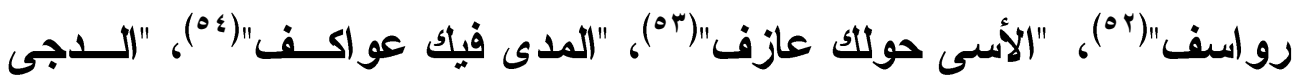

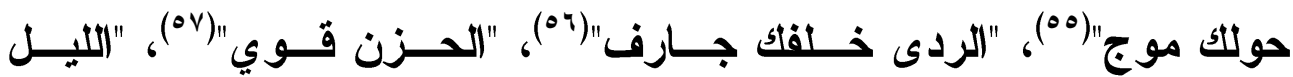

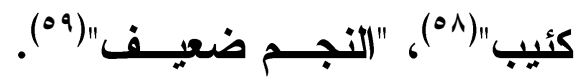

ج- المبتدأ معرفة (مضاف إلى معرفة)، والخبر نكرة وظهر في موضعين: "طرق الحياة إلى الممات ممهذة"(·")، "حكايات العذاب مجردة"("ا"). الثاني: المبتدأ معرنة، والخبر هعرفة

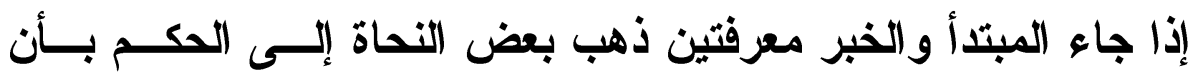

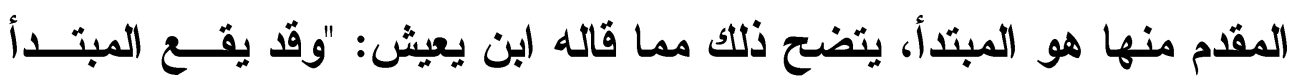

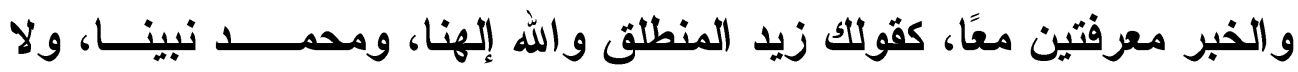

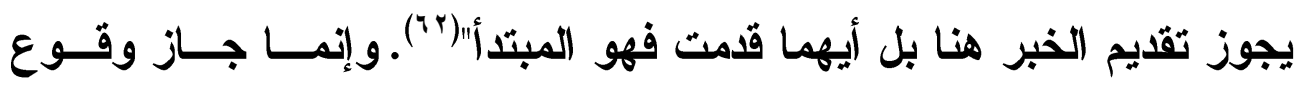
المبتدأ والخبر معرفتين، بشرط وقوع الفائدة المقصودة من الجملة الاسمية،

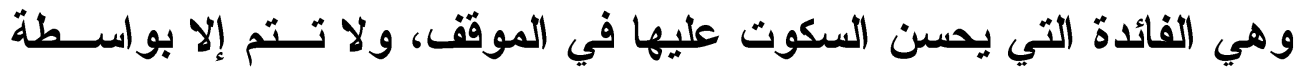
شيء يتعلق به الخبر ("יا"). وقد جاء هذا النمط في الديوان على النحو الآتي: أ. مبتدأ معرفة (ضمير) والخبر معرفة، ظهر في (ستة) مواضع:

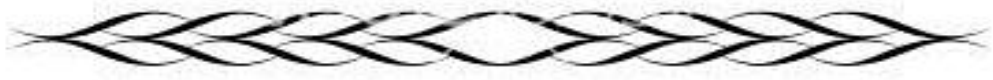




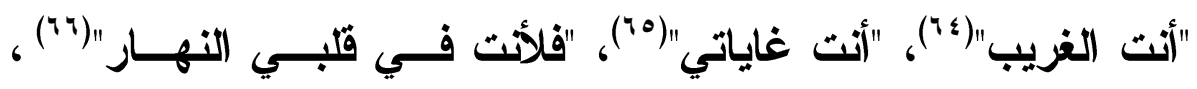

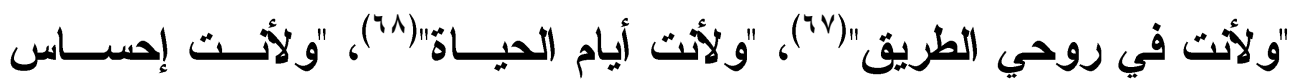

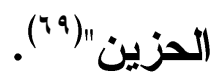

ب. المبتأ معرفة (اسم إثارة) والخبر معرفة، ظهر في موضع واحد:

$$
\text { في قوله: "هذي مكابرتي"(v"). }
$$

ت. المبتدأ معرفة (مضاف إلى ضمير المتكلم) والخبر معرفــة، ظهـر فـي موضع و احد:

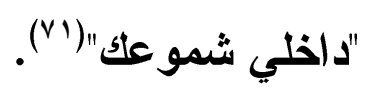

ث. المبتدأ معرفة (مضاف إلى ضمير الغائب) والخبر معرفــة، ظهـر فـي موضع و احد:

$$
\text { في قوله: "زاده الرحيل" (rvن). }
$$

ج.المبتدأ معرفة (مضاف إلى معرفة) والخبر معرفة، ظهر في موضع واحد: "كل الحكايا مثل قصتنا"("V).

\section{الثالث: المبتدأ همرفة والخبر جملة}

ذهب النحاة إلى القول بأن المبتدأ يكون خبره جملة، ذكر ذلك سيبويه

في الكتاب، "هذا باب ما يختار فيه إعمال الفعل مما يكون في المبتدأ مبنيــا عليه الفعل"(ع أ. وذهب النحاة إلى أن جملة الخبر تكون اسمية وتكون فعلية، واثثترطوا في جملة الخبر أن تثتثل على رابط يعود على المبتدأ، يكون هذا

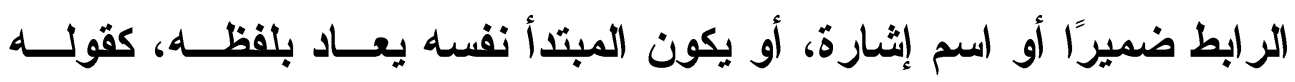

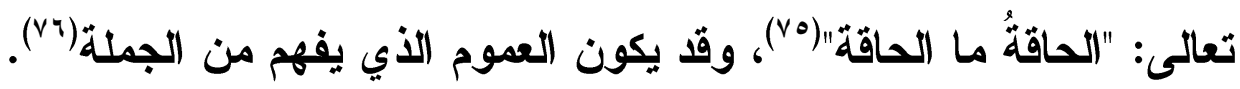


وقد ظهرت صورة المبتدأ معرفة والخبر جملة في ديوان فينيق الجراح على النحو الآتي: أولاً: المبتدأ معرفة والخبر جملة فعلية (فعل ماض): أ- المبتدأ معرفة (ضمير المتكلم) والخبر فعـل مـــاضٍ منفـي، ظهـر فـي موضعين:

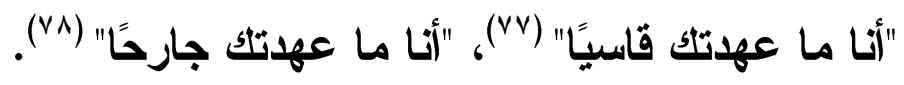
ب- المبتدأ معرفة (ضمير مخاطب) والخبر (فعل ماض)، ظهر فــي موضــع واحد:

$$
\text { "(أنت نملت "(va) }
$$

ت- المبتدأ معرفة (مضاف إلى ضمير المتكلم) والخبر فعل ماضٍ، ظهر فـي موضعين:

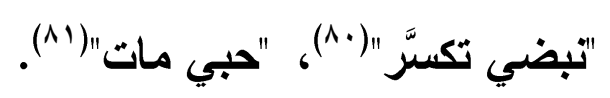

ث- المبتدأ معرفة (مضاف إلى ضمير المخاطب) والخبر فعل ماضٍ، ظهر في

$$
\text { موضع واحد: }
$$

$$
\text { "غرورك تعامى" (^r). }
$$

ج- المبتدأ معرفة (معرفة بال التعريف) والخبر فعل ماضٍ، ظهر فـي (أحسـ عشر موضعًا):

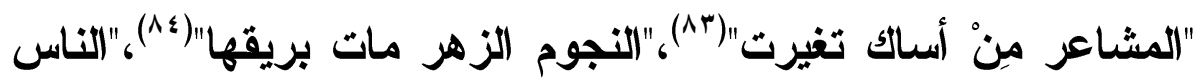

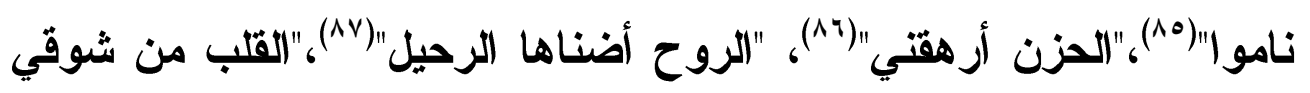




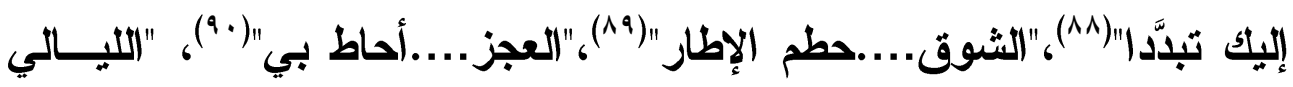

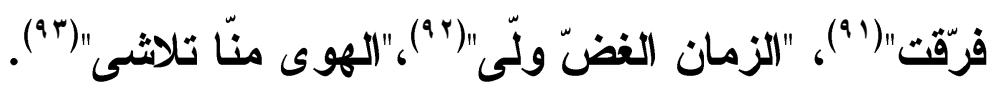

المبتدأ معرفة (معرف بال التعريف)، والخبر فعل (ماض مـن أفعـال

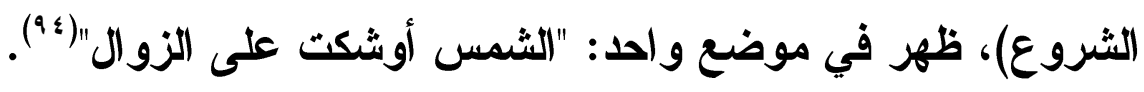

ح- المبتدأ معرفة (مضاف إلى معرفة بال) والخبر فعل مساضٍ، ظهـر فــي

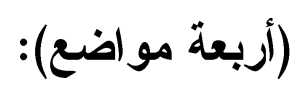

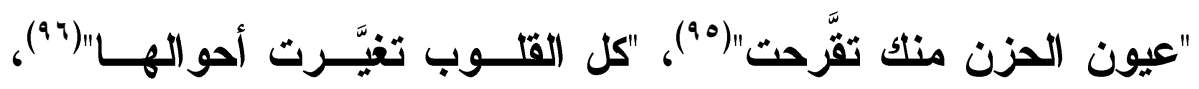

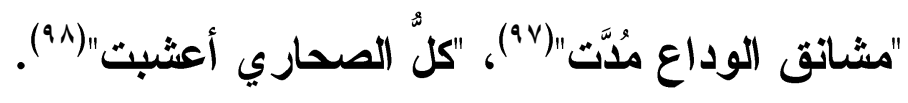
ثانيًا: المبتدأ معرفة والخبر جملة فعلية (فعل مضارع):

أ. المبتدأ معرفة (ضمير المتكلم) والخبر فعل مضارع، ظهر فـي (موضــع واحد):

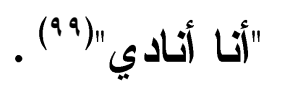

ب. المبتدأ معرفة (ضمير المخاطب) والخبر فعل مضارع، ظهر في (خمسـة مو (ضع):

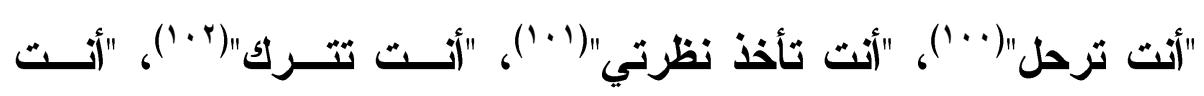

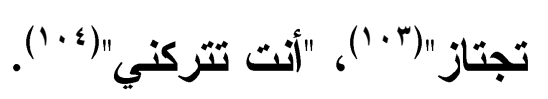

ت. المبتدأ معرفة (مضاف إلى ضمير المتكلم) والخبر فعل مضارع، ظهر في (تسعة مواضع):

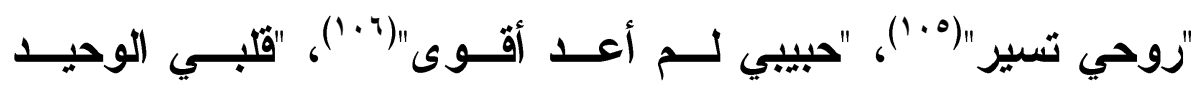

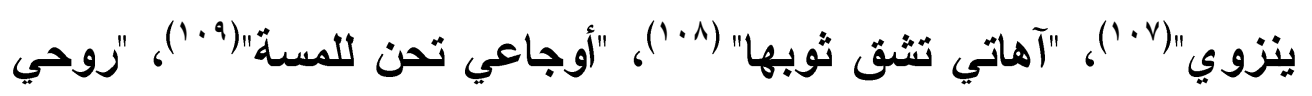


بناء الجملة النحوية (الاسمية الخبرية) في ديوان

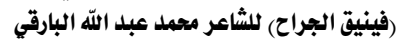

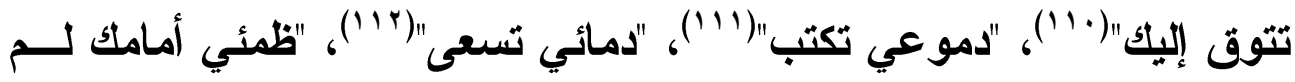

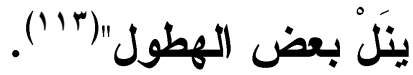

ث. المبتدأ معرفة (مضاف إلى ضمير المخاطب) والخبر فعل مضارع، ظهـر في (موضعين):

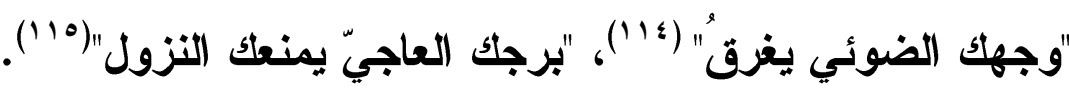

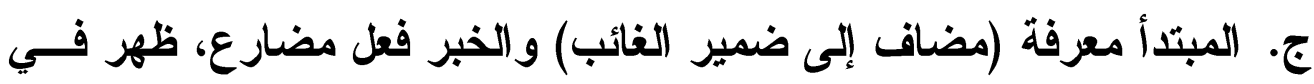
(موضعين):

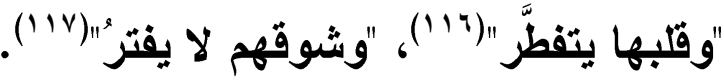

ح. المبتدأ معرفة (معرفة بال التعريف) والخبر فعل مضارع، ظهر في (تسعة عشر موضعًا):

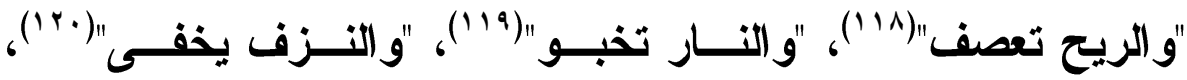

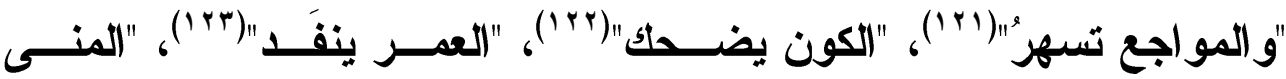

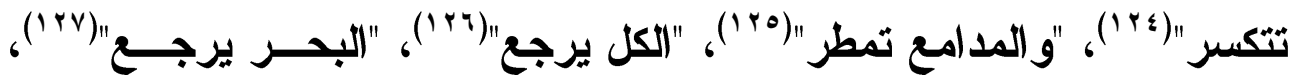

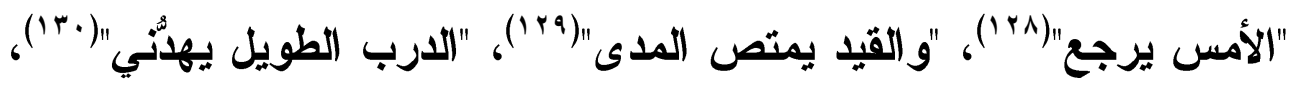

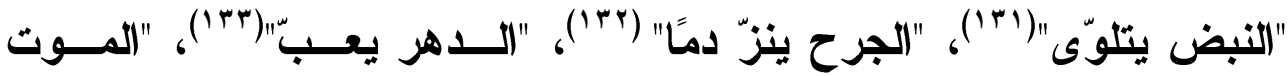

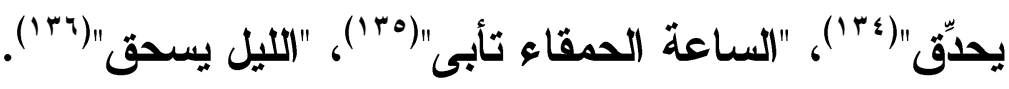
المبتدأ معرفة، بإضافته إلى مُعرَّت بالإضافة إلى الضمير والخبر جملة

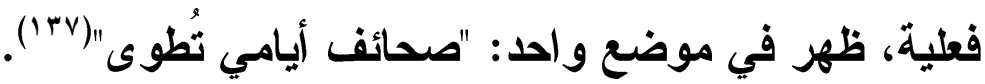
المبتأ معرفة (بالإضافة إلى معرف بال التعريف) والخبر فعل مضارع.

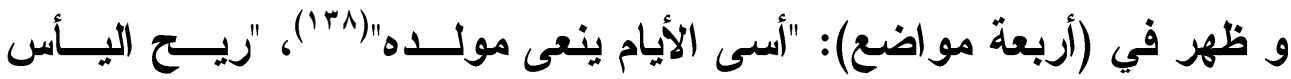

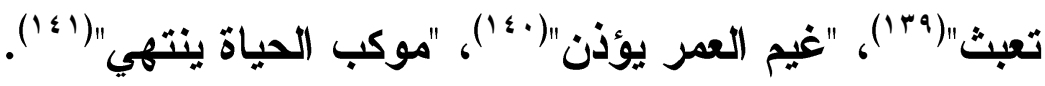

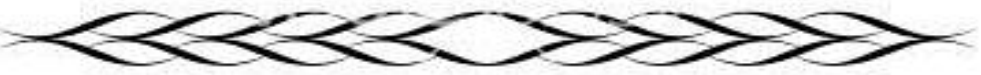


ثالثاً: المبتدأ معرفة والخبر جملة فعلية فعلها ناسخ:

لم يأكر النحــاة أن الجملة الفعلية الناسخة يمكن أن ثقع خبرًا، وما قـ يفهم من أقوالهم يفيد بأنهم عدوها من الجملة الفعلية، يؤيد ذلك مـــا ذهــب إليه ابن هشام، حين مثَّل للجملة الفعلية قائلًا: " والفعلية هي التي صــدرها

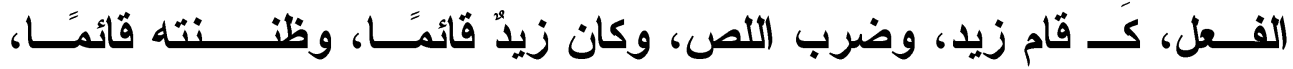

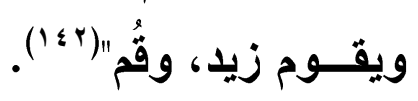

وقد ظهر المبتدأ معرفة والخبر جملة فعلية فعلها ناســـخ فــي أربعــة

مواضع:

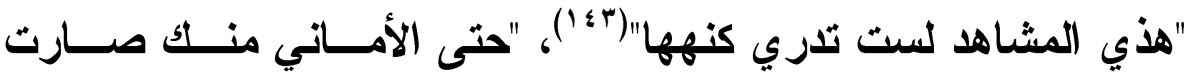

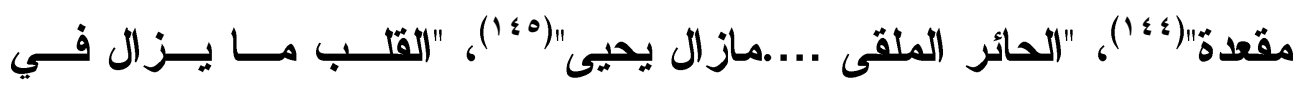
(نتظار (1) (1) (1)

رابعًا: المبتدأ معرفة والخبر جملة اسمية: أجمع النحاة على القول بأن جملة الخبر تكون اسمية وفعلية، وذكرث ذلــك فــي موضـــع ســابق مــن البحث(1٪ "هذه (الحياة هي الرحى تُار "(^؛)، المبتدأ معرفة اسم إثـارة، والخبـر جملة اسمية (مبتدأ ضمير وخبر معرف بـ (ال). "وليلك أنت مسلـع العـين

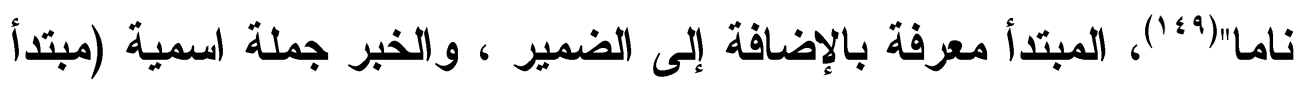
معرف بإضافته) إلى معرف بـ (ال) وخبر فعل ماض. 


\section{الرابع: المبتدأ همرفة والخبر شبه جملة:}

أجمع النحاة على جواز مجيء شبه الجملة خبرًا، غير أنهم اختلفوا في تأويل الخبر، أهو الظرف والجار والمجرور نفسه أم الاسم المقدر المحذوف

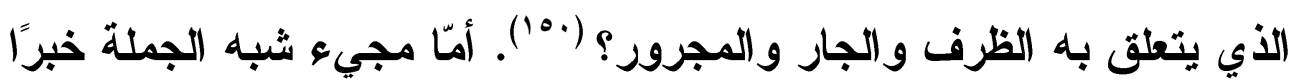

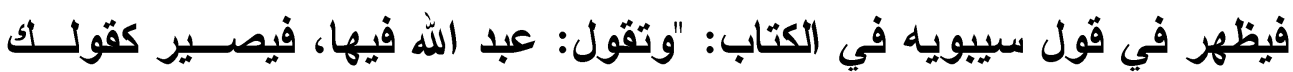
عبد الله أخوك، إلّا أنّ عبد الله يرتفع مقدمًا كان أو مؤخرًا بالابتداء"(101). وقد أجاز ذلك وتابعه من النحاة كثيرون(rم"). أمّا بشأن خلاف النحــاة في تأويل الخبر، فلن أطيل الحديث فيه؛ لأن غرضي في البحث الوقوف على أنماط الجملة الاسمية الخبرية الواردة في الايوان؛ وحصرها لمعرفة مــى

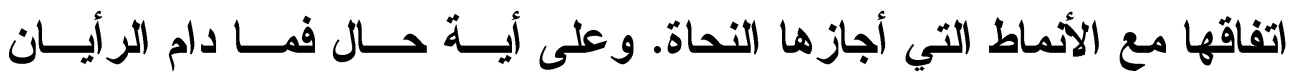
جائزين فأرى أن معنى التركيب النحوي، الأي ورد فيه الخبر(شبه جملــة) يرجّح الر أي الأي ينبخي الأخذ به، فُإن كان المعنى لا يصح إلّا بتقدير متعلق

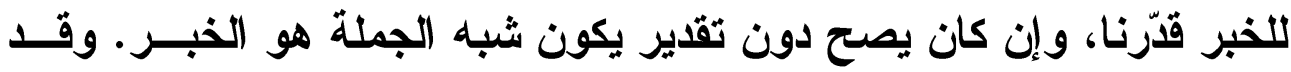
ورد هذا النمط في ديوان فينيق الجراح في صورتين:

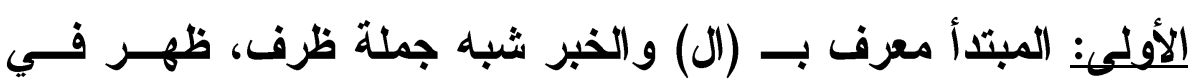

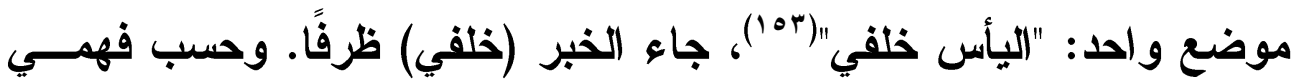
للجملة في الايوان فأرى أن الأولى هنا عدم التقدير، ويكون (خلفــي) خبـر (اليأس)؛ لأن الثاعر أراد أن يبين إحساسه باليأس الأي لازمه، وكان خلقه في لحظة هروبه إلى المخاطب؛ لأن الهارب يبتعد عن مصدر الخطر، الــذي يهرب منه، فيكون خلقه بالضرورة ، ممَّا يجعل هذا المعنى أدق من معنـى (مستقر خلفي) الأي يتأتَّى بتقدير. 
الترقير الدولخ 2356-9050 235

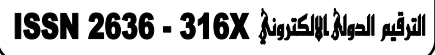

(T) 1918

حولية كلية اللفة العربية بجرجا مجلة علمية محكمة

كما يتضح في قول الثاعر:

أتيتك هاربًا واليأس خلفي فعلت تسوقني الآلام : هيَّا (10 )

الثثانية: المبتدأ معرف بال وشبه الجملة جار ومجــرور، ظهـر فــي

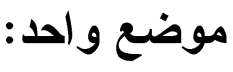

$$
\text { "الأسى من كل صوب"(100) }
$$

وأرى أن (من كل صوب) خبر، دون تقدير محذوف؛ لأن الثاعر أراد

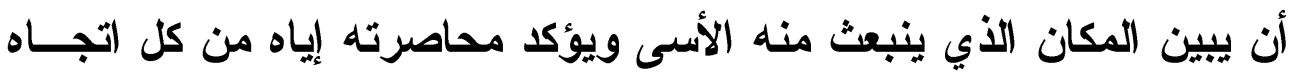

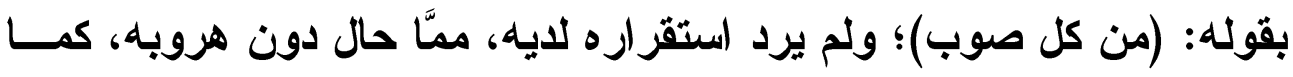
يظهر في قوله:

كيف بالله الهروب (107) - (10) فالأسى من كل صوب

\section{الابتداء بالنكرة}

المبتدأ لا يأتي إلا معرفة، أو ما قارب المعرفة من النكرات، كما سبق

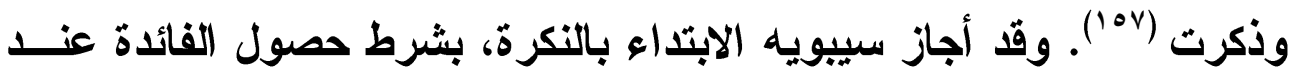

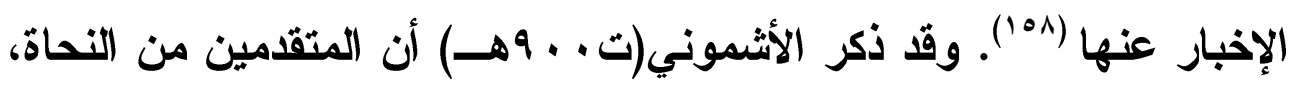

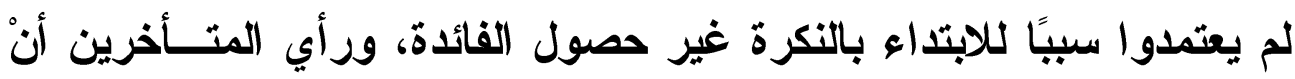
ليس كل الناس قادرين على الاهتداء لمواطن الفائدة، وتتبعوها، فمنهم قلإها

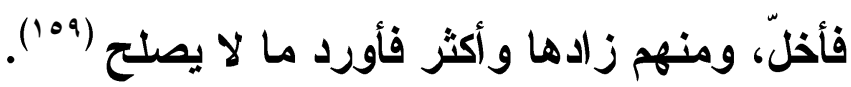

ظهر الابتداء بالنكرة في ديوان (فينيق الجراح) حسب الأمماط الآتية: - مبتدأ نكرة محضة والخبر نكرة محضة، ظهر في ثلاثة مواضع: 
بناء الجملة النحوية (الاسمية الخبرية) في ديوان (فينيق الجراح) للشاعر محمد عبد اللّا البارقي في داني

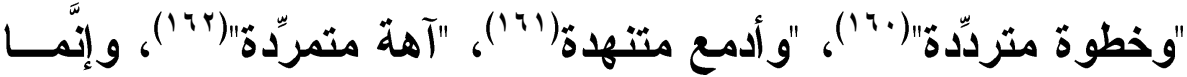

جاز الابتداء بالنكرة؛ لأكها سبقت بواو الحـــال فســاغ الابتــــاء بــالنكرة: (خطوة)، (أدمع)، (آهة)؛ لتقدم واو الحال عليها(بrا").

أ- المبتدأ نكرة موصوفة الخبر جملة فعلية، ظهر في موضعين:

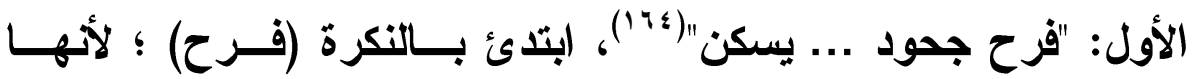

موصوفة بـ (جـــود)، إذ مــن مســوغات الابتــــاء بــالنكرة أن تـأتي موصوفة (170).

الثاني: "ومدامعُ حمراء أذبلها الهطول"(14)، إذ سوّغ مجيء (مـــ(مع)

$$
\text { مبتدأ نكرة؛ لأنها وصفت بـ (حمراء). }
$$

ب- المبتدأ نكرة مقيَّة بشبه جملة والخبر جملة فعلية، ظهر فـي موضـع واحد: "وجع بعمق الليل يسبح" (IVV).

المبتدأ نكرة مفيّدة بشبه جملة والخبر جملة فعلية مصــدرية، فعلهـا

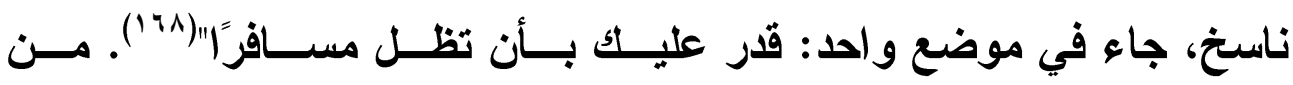

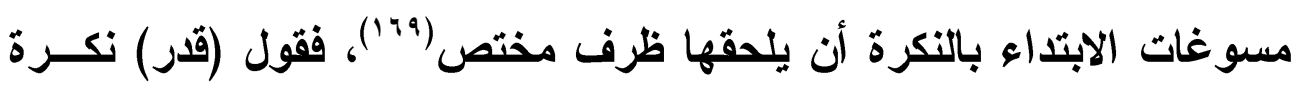
لحقها (عليك) وهو ظرف مختص.

" نكرة معطوف عليها والخبر جملة فعلية، في موضع واحد:

"قفر وغول يمزقني"(·"lv). وسوَّغ الابتداء بالنكرة؛ أنها جاعت معطوف

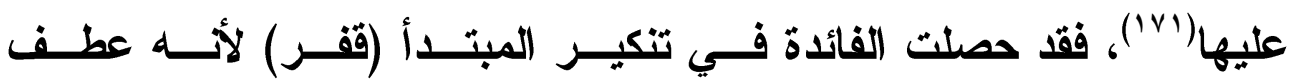
عليه(غول)

ت-نكرة محضة والخبر جملة فعلية، ظهر في (سبعة مواضع): 


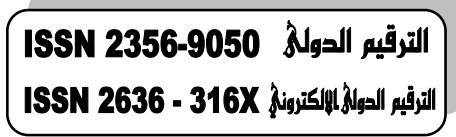

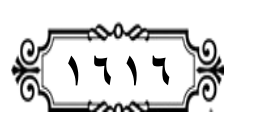

حولية كلية اللفة العربية بجرجا مجية مجية مجلة علمية محكمة

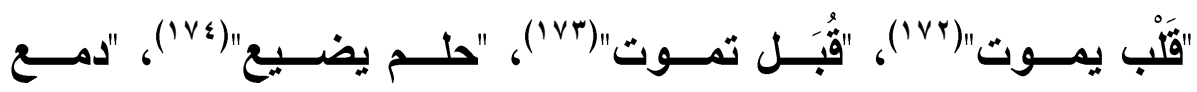

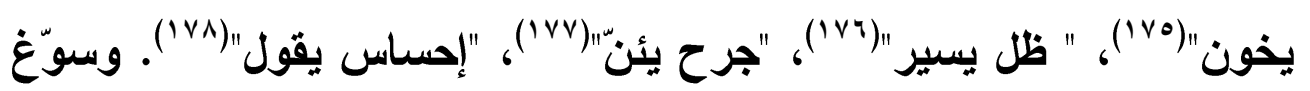

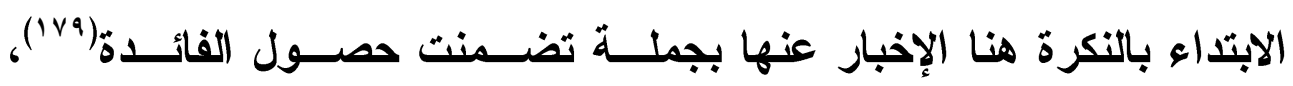
وظهرت هنا بالجملة الفطية: (يموت)، (تموت)، (يضيع)، (يخون)، (يسير)،

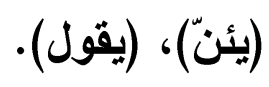

\section{تقديم الخبر على المبتدأ}

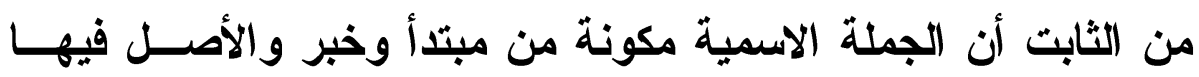

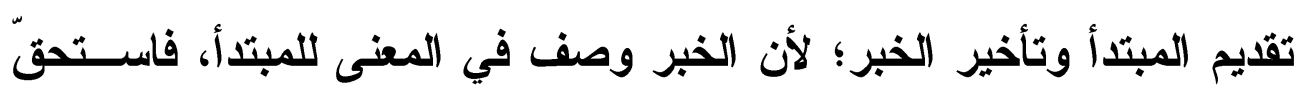

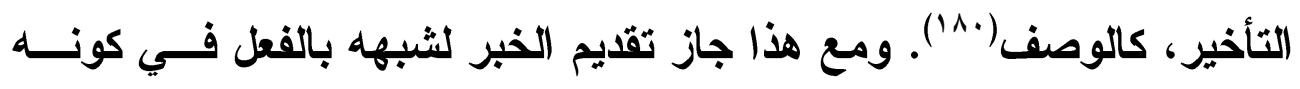

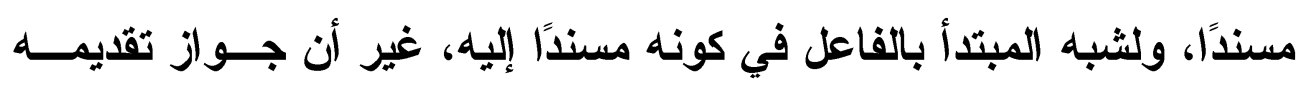
مشروط بأمن اللبس (1'ا'). وسأوضح المواضع التي تقدم فيها الخبر على المبتدأ في ديوان (فينيق

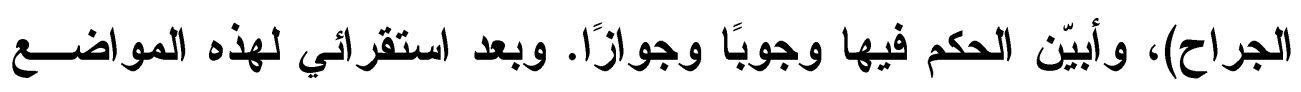
في الديوان وجدتها على النحو الآتي:

\section{أولا: تقديم الخبر على المبتدأ وجوبًا} الخبر شبه جملة والمبتدأ نكرة

من الحالات التي ذكرها النحويون، أن يكون تقـــيم الخبـر مصـــــاً

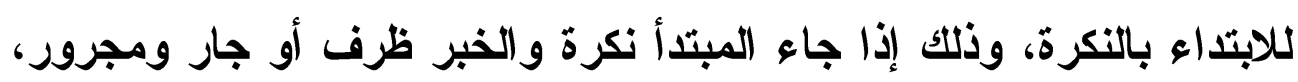

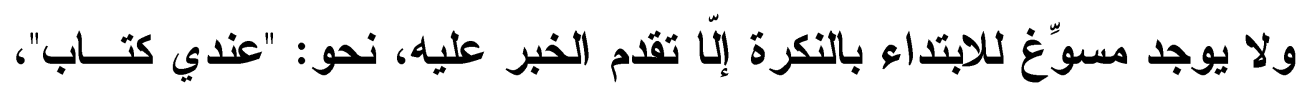

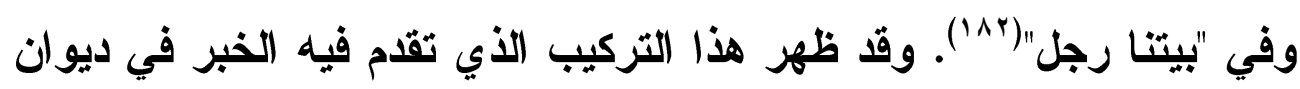

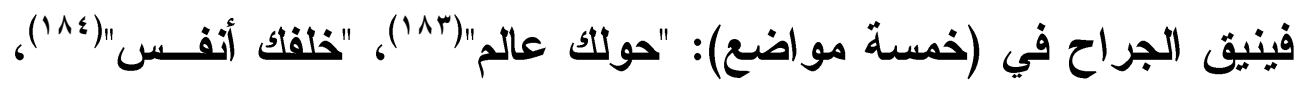




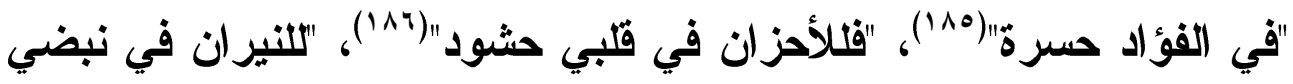

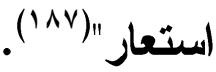

\section{ثانياً: تقديم الخبر على المبتدأ جوازًا}

أ- الخبر جملة والمبتدأ نكرة موصوفة، وفيـهـه يجــوز تقــيم الخبــر

وتأخيره، نحو: (عندك كتاب جميل)، (على المكتب قلم نفيس)، ويجوز (كتاب

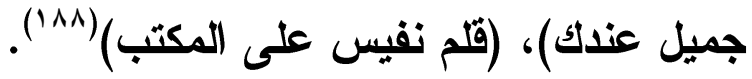

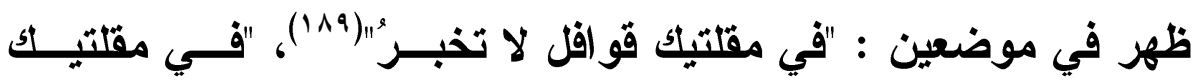

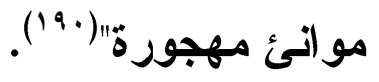

ب- الخبر شبه جملة والمبتدأ معرفة، من المواضع التي ذكرها التحـــاة،

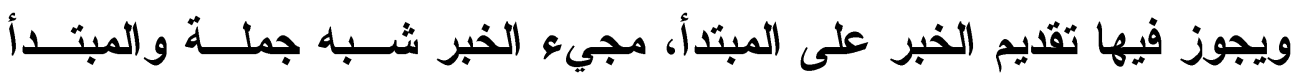

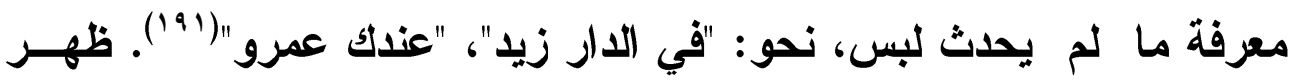

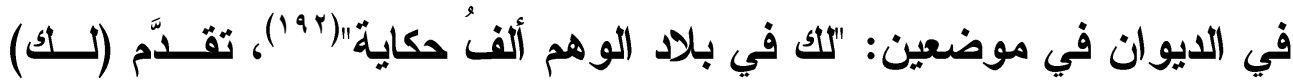

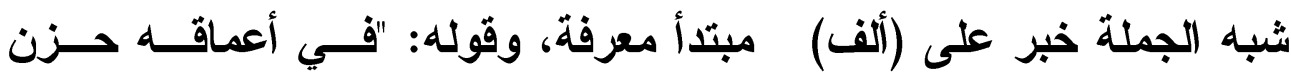
اليتامى"("و')، تقدم (في أعماقه) خبر على (حزن) مبتدأ معرفة.

ج- الخبر معرفة والمبثدأ معرفة، ذكر ابن مالكك بأن المبتدأ والخبر إذا كانا معرفتين أو نكرتين وجب تقديم المبتدأ؛ لأهه لا يتم تمييز الخبر إلّا بذلك، مهئ

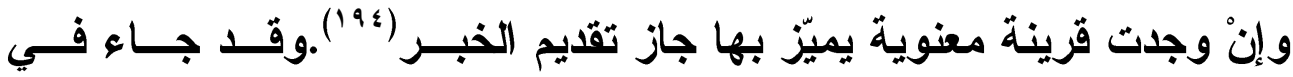
الايوان في موضع واحد الخبر معرفة متقدمًا على المبتــــأ المعرفــة فــي: "جزيرة الاجى أنا"(190)، و إنما جاز لذانلك لسبيين:

أولًِا: ما ذكره النحاة من القول بأن أعرف المعارف بعد لفـــ الجلاهـــة وضميره، الضمائر، وأولها ضمير المتكلم(197)، وبما أن الأصل في المبتـــأ

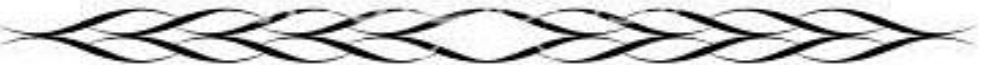


التعريف، واجتمع مع خبر معرفة في تركيب واحد، فالأولى أن يكون المبتدأ

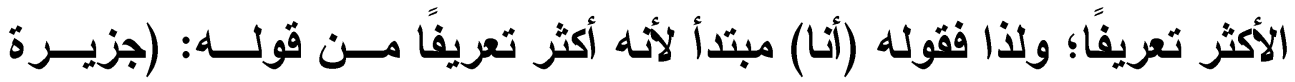
(الاجى).

ثناتبًا: المعنى يقتضي أن يكون (أنا) في الجملة مسندًا إليه، و(جزيــرة

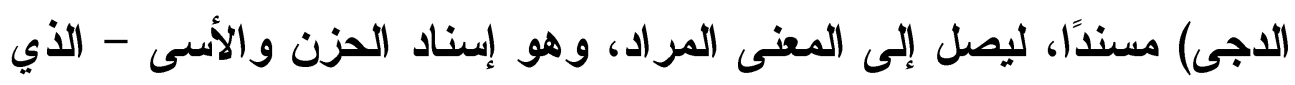
لا منفذ فيه للفرح - إلى نفسه.

\section{الجملة الاسمية الصدرة ب(إنّ) أو إحدى أخواتها}

عدّ النحاة (إنّ)وأخواتها من نواستخ الابتداء؛ لما تحدثه من تغيّر فـي حركة كل من المبتدأ والخبر، وفي نسخ مكانة الصدارة في الجملة إلـى أداة

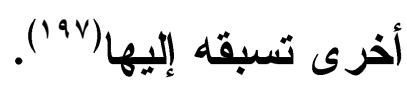

ويتمثل أثرها في الجملة الاسمية في أنها تنصب المبتدأ وترفع الخبر،

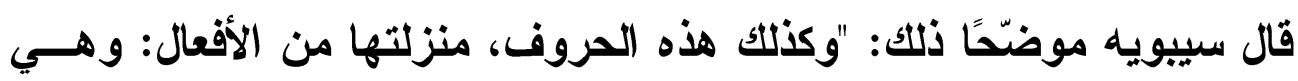

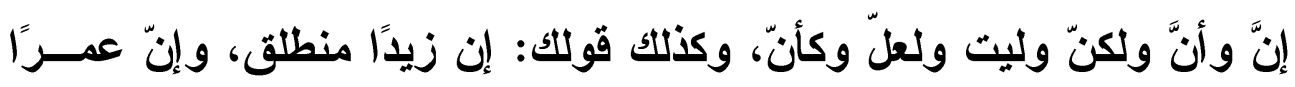
مسافر، وإنّ زيدًا أخوك، وكذلك أخواتها، وزعم الخليل أنها عملت عملـينين:

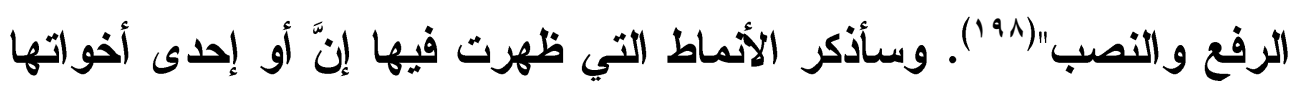
بالتفصيل في ديوان (فينيق الجراح). وبعد استقصائي لهذه الأمماط وجلتها على النحو الآتي: أولاًا: إنّ أو إحدى أخواتها واسمها هعرفة وخبرها نكرة وقد تقدّم الاسم المعرفة على الخبر النكرة ، وهو ما أطلق عليه النحاة

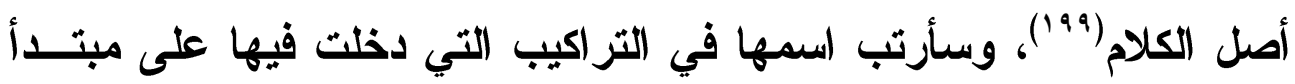
معرفة وخبرها نكرة، حسب ترتيب المعارف الأي اتبعته في الجملة الاسمية. 
وقد ظهر هذا النمط في صور عدة على النحو الآتي:

أ. إنّ واسمها ضمير متكلم وخبرها نكرة، ظهر في موضعين:

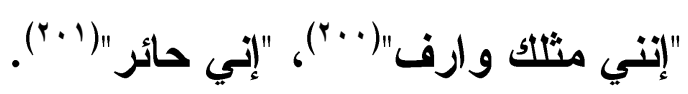

ب. لكنَّ واسمها معرف بالإضافة إلى الضمير والخبر نكرة، ظهر في موضــع

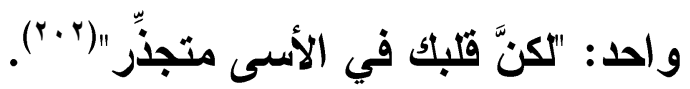

ت. إنَّ واسمها معرف بال والخبر نكرة، ظهر فـي موضــعين: "أن المــوت

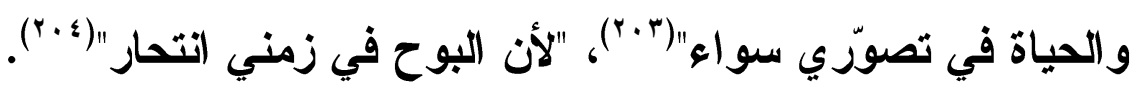

\section{ثانياً: إنّ واسمها همرفة وخبرها همرفة} وظهر في الديوان على النحو الآتي:

أ- أنَّ و اسمها ضمير منكلم والخبر معرفة، ظهر في موضعين:

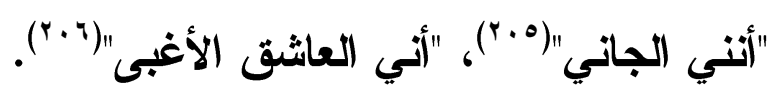
ب- كأنَّ واسمها ضمير غائب والخبر معرفة، ظهر في موضع واحد:

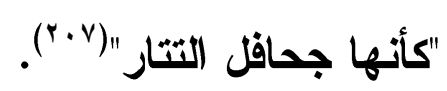

ت- أنّ واسمها مضاف اسم ضمير والخبر معرفة، ظهر في موضع واحد:

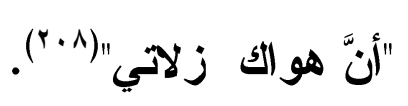

ثالثاً: (إنَّ) أو إحدى أخواتها واسمها همرفة وخبرها جملة فعلية (فهل هاض) وقا ظهر في الايوان على التحو الآتي:

أ. (إنّ) واسمها معرفة مضاف إلى ضمير المتكلم، والخبر جملة فعلية (فعل

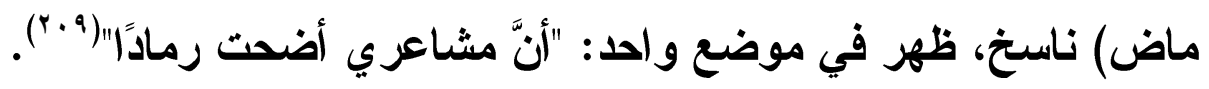


ب. (إنّ)) أو إحلى أخواتها واسمها معرفة (معرف بال) والخبر جملة فعليـة (فعل ماض)، ظهر في (خمسة مواضع):

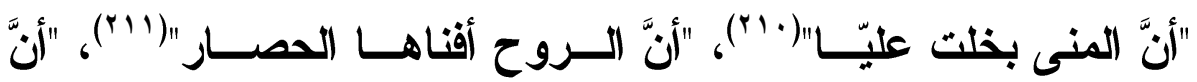

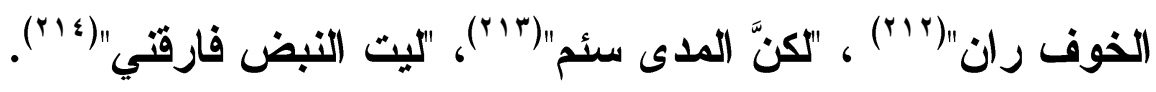

ت. (إنَّ) أو إحدى أخو اتها واسمها معرفة (بالإضافة إلـى معرفــة) والخبــر

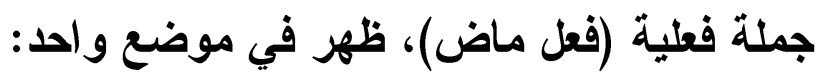

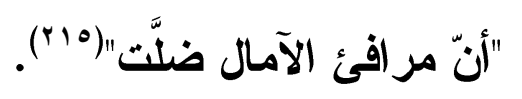

ث. (ليت) و اسمها معرف بال وخبرها ماضٍ ناسخ، ظهر في موضع واحد:

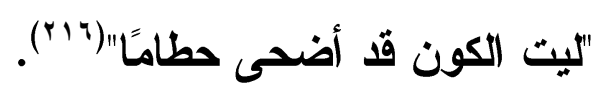
رابعاً: (إنَ) أو إحدى أخواتها والخبر جملة فعلية (فعل هضارع) جاء هذا النمط في الديوان على النحو الآتي: أ- (إنَّ) أو إحدى أخو اتها واسمها معرفة مضاف إلى ضمير المتكلم، والخبر فعل مضارع، ظهر في (أربعة مواضع):

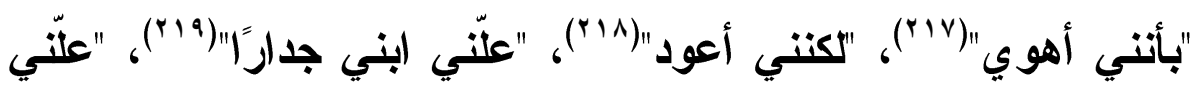

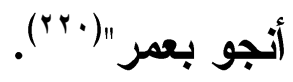

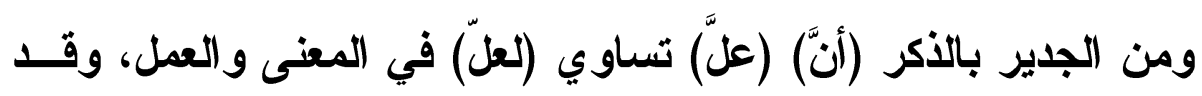

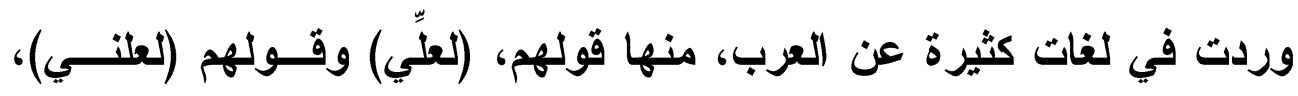

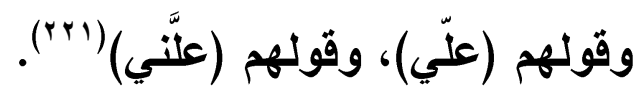

ب- (لعلَّ) واسمها ضمير المتكلم والخبر جملة فعلية (فعل مضارع)، ظهر في وفي وفي موضع واحد: 

الجزء الثاني

"كلثّك تمنح"(rrr")

ت- (لكنَّ) واسمها ضمير (الغائب والخبر جملة فعلية (فعل مضارع)، ظهر في موضع واحد:

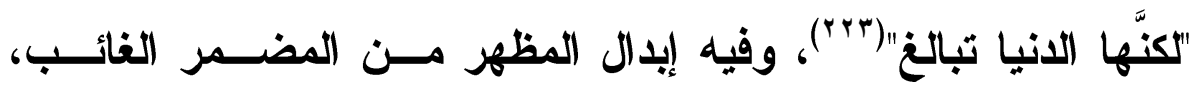

و(الدنيا) بدل من (الها) في (لكنها)، ف(الدنيا) بال من (الهاء) في (لكنها) ،

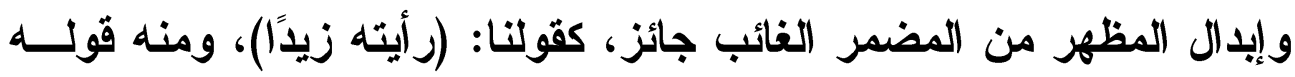

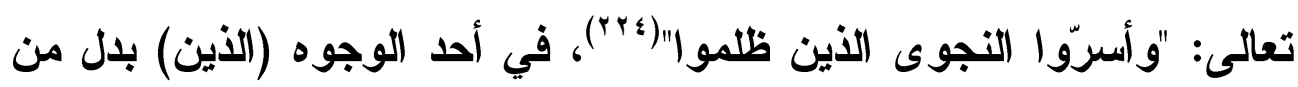

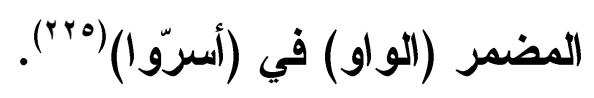

ث- (إنّ) أو إحدى أخواتها واسمها معرفة (معرف بال) والخبر جملة فعليــة

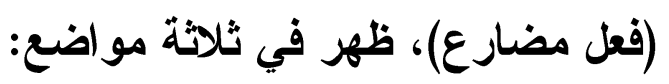

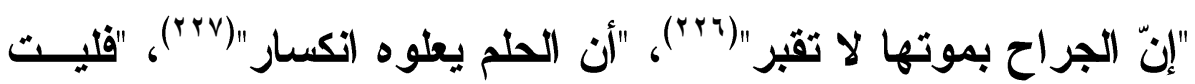

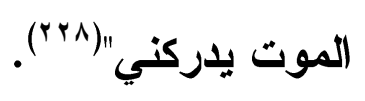

خاهساً: (إنَ) أو إحدى أخواتها واسمها هعرنة وخبرها ناسخ

ظهر في الديوان على النحو الآتي:

أ- (لكنَّ) واسمها ضمير المتكلم وخبرها ناستخ، ظهر في موضع واحد:

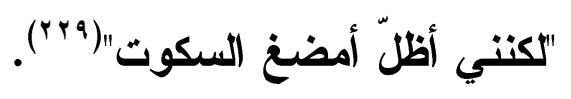

ب- (ليت) و اسمها ضمير المخاطب، وخبرها ناسخ، ظهر في خمسة مواضع:

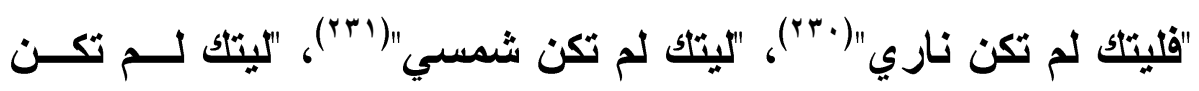

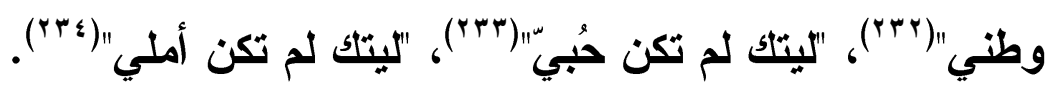


تـ- (أنَّ) و اسمها معرفة بالإضافة إلى معرف بال والخبر ناستخ، ظهـر فــي

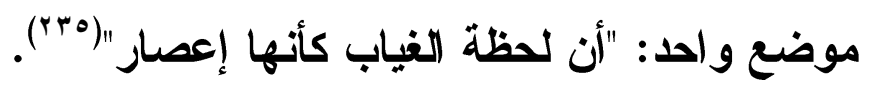

\section{تقديم خبر (إن) أو إحدى أخواتها على اسمها \\ تقديم خبرها على اسمها وجوبا}

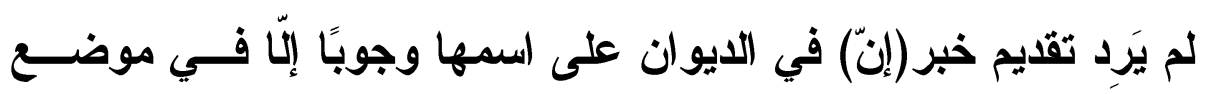

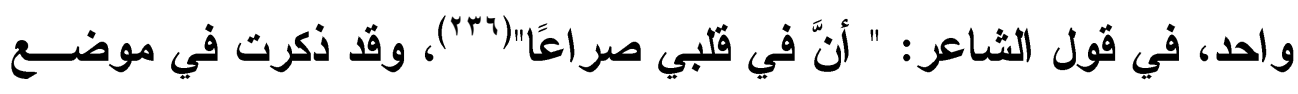

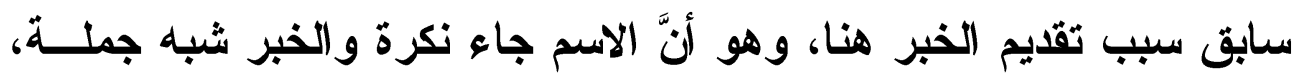

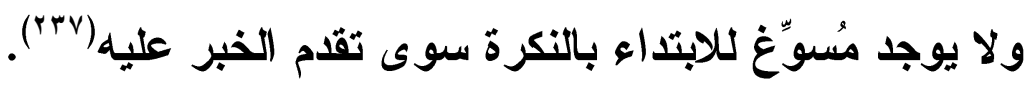

\section{الجملة الاسمية الصدرة بـ (لا) النافية للجنس}

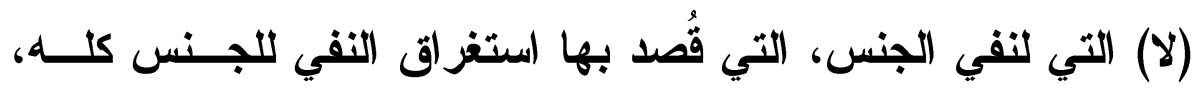

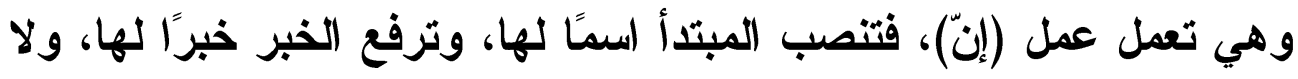

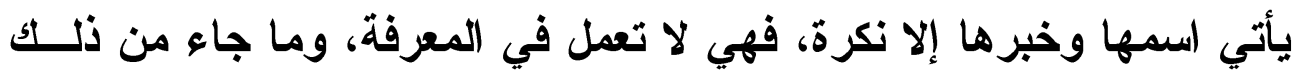

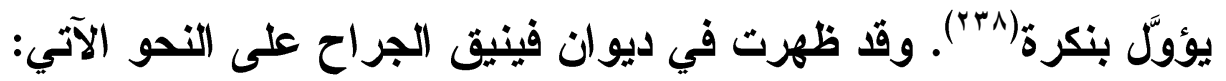

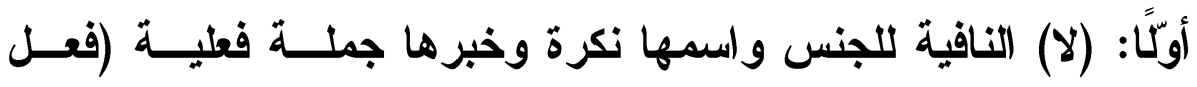

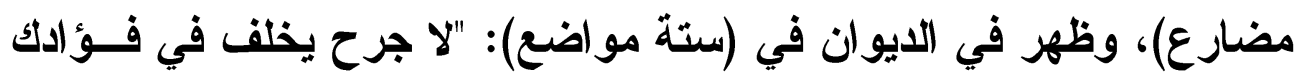

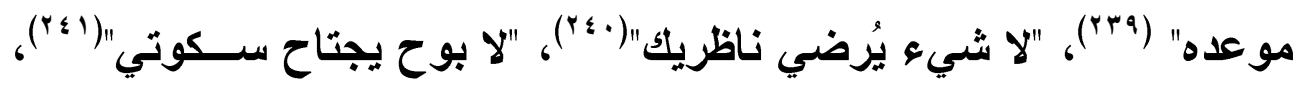

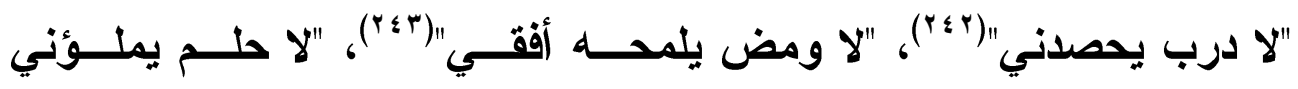

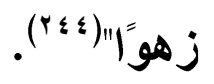

ثاتيًا: (لا) النافية للجنس واسمها نكرة وخبرها نكرة مقدرة ، ظهر في

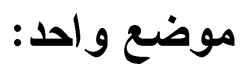




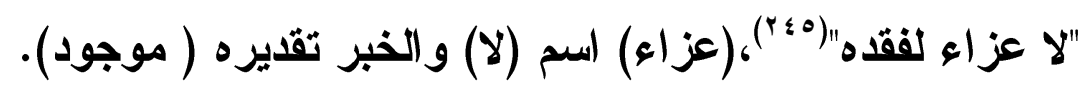

\section{البمهلة الاسمية المسدرة بـ (كان) أو إحدى أخواتها}

تعدّ (كان) وأخواتها من نواستخ الابتداء؛؛ لما ذهب إليه معظـــ النحـــاة

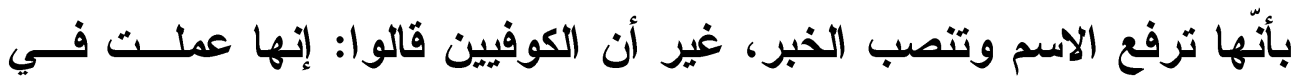

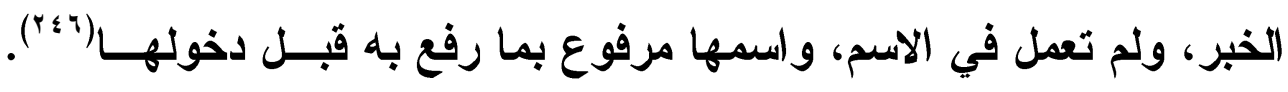

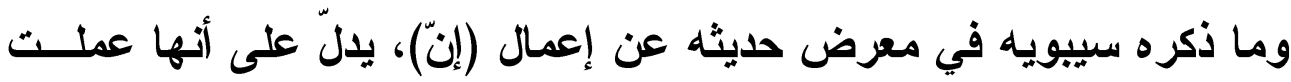
في الاسم كما عملت في الخبر، وذلك نقلًا عن الخليل: "وزعم الخليـلـل أنهــا عملت عملين : الرفع والنصب كما كان الرفع والنصب حين قلت: "كان أخاك

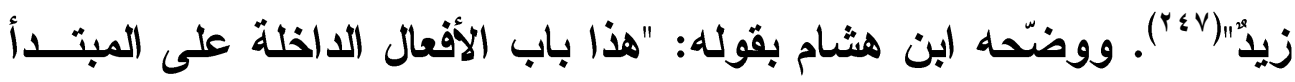
والخبر، فترفع المبتدأ تشبيهًا بالقاعل ويسمّى اسمها، وتنصب خبره تشبيهًا بالمفعول ويسمّى خبرها"(^§؟). وما أراه أن الأولى القول بإعمالها في الاسم والخبر معًا؛ لأكها عملت تشبيهًا بالقعل التام، فإذا عمل لن يعمل في جزء من القول ويترك جزعًا، دون علّة تفسرّ ذلك. وأخوات (كان) التي تعمل عملها - كما ذكر النحــاة - هـــي: صــار و أمسى وأصبح وظلّ وبات وأضحى وما دام وما زال وما انقلكَّ وما فتئ وما

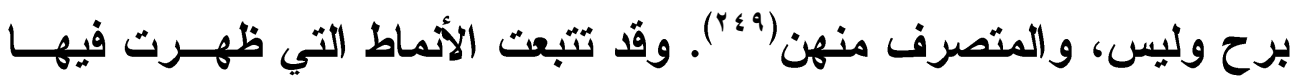
(كان) أو إحدى أخواتها في ديوان فينيق الجراح، فوجدتها على النحو الآتي:

\section{أولاً: (كان) أو إحدى أخواتها واسمها همرفة والضبر نكرة}

وسأرتّب الاسم في هذا التركيب (الاسم معرفة والخبر نكــرة) حسـب تزتيب المعارف الأي اتبعته في الجملة الاسمية، وفـي الجملــة المصـــرة ب(إنّ) أو إحدى أخواتها. 
وقد ظهر هذا النمط في صور عدة على النحو الآتي:

أ. (تظل) و اسمها ضمير منكلم والخبر نكرة، ظهر في موضعين:

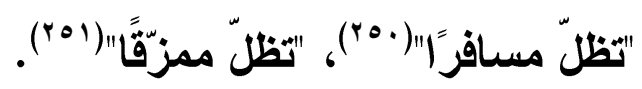

ب.(كان) أو إحدى أخواتها واسمها ضمير غائب والخبر نكرة، ظهر في

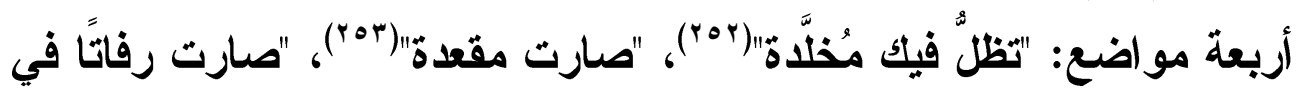

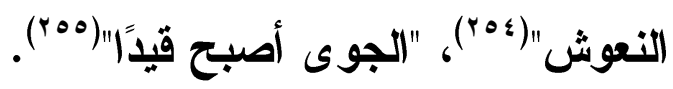

ت. (كان) أو إحدى أخواتها واسمها معرف بال والخبر نكرة، ظهر في

موضعين:

"صار الغدرُ صوتًا"(ror)، "صار اليأس غولًا"(rov).

ث. (كان) واسمها معرفة بإضافته إلى ضمير الغائب والخبــر نكــرة، ظهر في موضع واحد: "ما كان يومًا لغيرك نبضُه إلّا حر امًا (ro1).

ج. (كان) أو إحدى أخواتها واسمها معرف بإضاقته إلى معرف بــال،

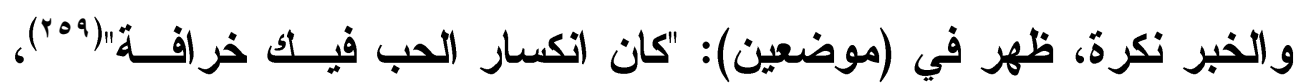
"صارث ظلال الشك فيك مؤكدة"(·rr").

ثانياً: (كان) أو إحدى أخواتها واسمها معرفة وخبرها همرفة (هصدر هوؤل )

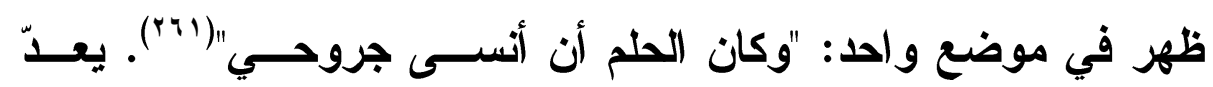

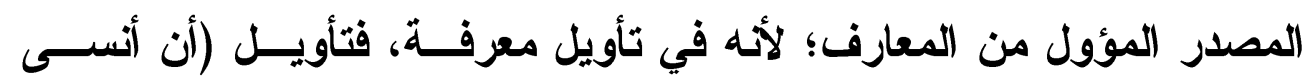
جروحي) مصدر صريح هو (نسيان). 
ثالثا: (كان) أو إحدى أخواتها معرفة والخبر جملة فعلية (فعل هضارع)

ظهر هذا النمط على النحو الآتي:

أ- (ما زال) واسمها ضمير متكلم والخبر جملة فعلية (فعل مضارع)، ظهـر

$$
\text { في موضع واحد: "ما زلت تحمل في الفؤاد مشاهدًا"(rاrr). }
$$

ب- ما زال واسمها ضمير غائب والخبر جملة فعلية (فعل مضارع)، ظهر في

ثلاثنة مواضع:

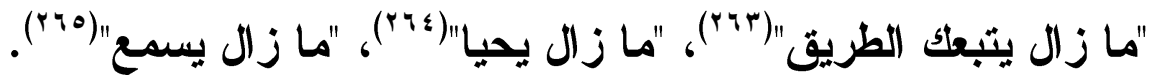

\section{رابعا: (كان) واسمها همرفة والخبر جملة اسمية}

ظهر في موضع واحد: "تكون حينها الحبوب داخل الرحى"(باr؟) اســم

كان ضمير متكلم مستتر تقديره (نحن) والخبر جملة اسمية (الحبوب) مبتدأ معرفة، والخبر (داخل) ظرف مكان.

خاهساً: كان أو إحدى أخواتها واسمها همرفنة، والخبر شببه جملة

وقا ظهر على النحو الآتي:

أ. (ما تزال) واسمها ضمير منكلم والخبر شبه جملة، في موضعين:

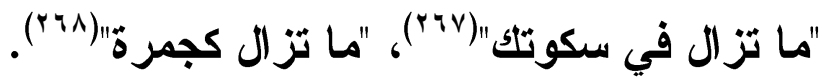

ب. (ما يزال) واسمها ضمير غائب والخبر شبه جملة، ظهر في موضع واحد: "ما يز ال في (نتظار "(r9q).

ث. (كان) واسمها معرف بال والخبر شبه جملة، ظهر في موضع واحد:

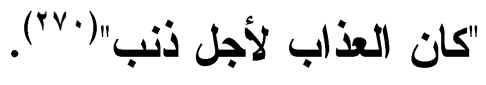




\section{تقديم خبر كان أو إحدى أخواتها على اسمها \\ تقديم خبرها على اسمها وجوبا}

لم يرد تقديم خبر (كان) أو إحدى أخواتها على اسمها وجوبًا، إلّا فـي

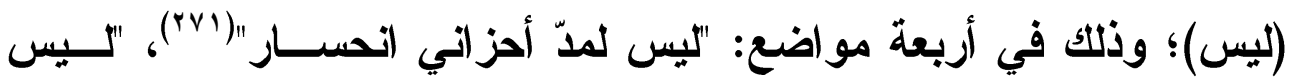

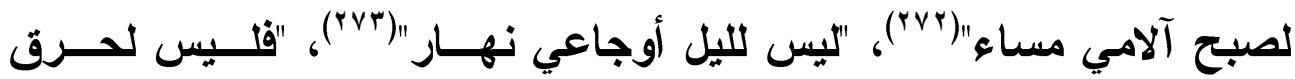
روحي من دواعِ"(؟V). وقد ذكرت - في غير موضع - سبب تقـــيم الخبــر هنا، وهو أنّ الاسم جاء نكرة والخبر شبه جملة، ومسوّغ الابتداء بــالنكرة تقدم الخبر عليd(rvo(r).

\section{أفعال الإقاربة والرجاء والشروع}

أفعال المقارنة وهي: (كاد)، و(كرب)، و(أوشك)، وضعت للالاكة علـى ألى قرب الخبر، وأفعال الرجاء وهي: (عسى) و(حــىى) و(أخلولـقن) وضـــت للالامة على رجاء الخبر، وبقية الأفعال للالالة على الشروع في الخبر وهي

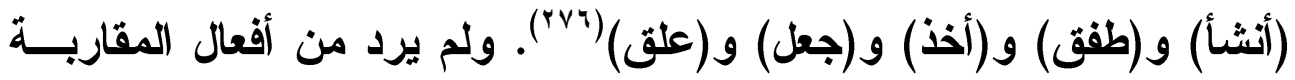
و الرجاء والشروع في الايوان سوى (أوشك) واسمه ضــمير الغائسب(هي) والخبر شبه جملة، في موضع واحد في قــول الشــاعر: "أوشــكت علــى

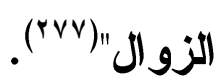




\section{هذف البملة الاسمية}

\section{حذف المبتدأ}

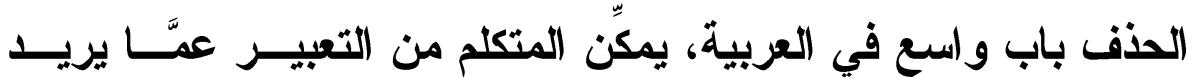

بايجاز شديد، دون أن يحدث خلل في التركيب، إذ إن المتكلم لا يحذف شــيئ

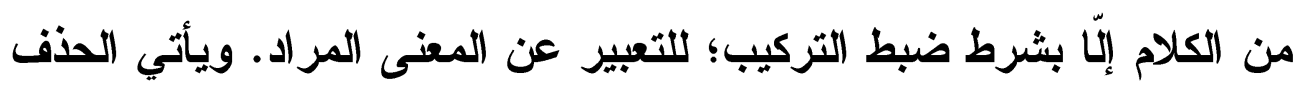
واجبًا في مواضع وجائزًا في غيرها.

\section{هن أحكام حذف المبتدأ وجوباً:}

ا ـإذا كان الخبر نعتًا مقطوعًا عن منعوته، وذلك في سياق المدح أو الأم أو

r ـ إذا كان مخصوصًا بالمدح والأم، وقد تأخر عن جملة المدح أو الأم. ب.إذا كان الخبر صريحًا في القسم، ومعلومًا لاى الناس، نحو: فــي ذمتـي

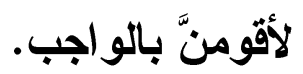

ع. إذا كان الخبر مصدرًا، يؤدي معنى فعله في أساليب معينــة، نحو(عمـلـل

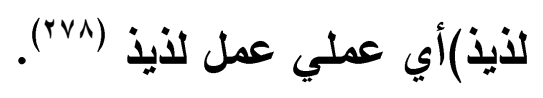
ولم يرد المبتدأ محذوفًا وجوبًا في ديوان فينيق الجراح.

\section{هذف المبتدأ جهوزاً:}

إذا جاء المبتدأ معلومًا في الكلام جاز حذفه (rva). وأرى أنّ المبتدأ جاء محذوفًا جوازًا في غير موضع في ديوان فينيق الجراح، ومن ذلك قوله:

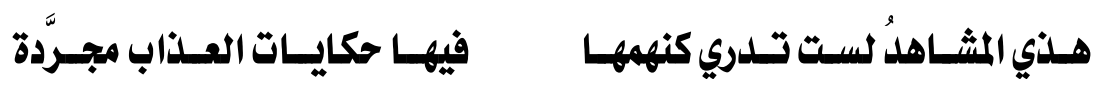

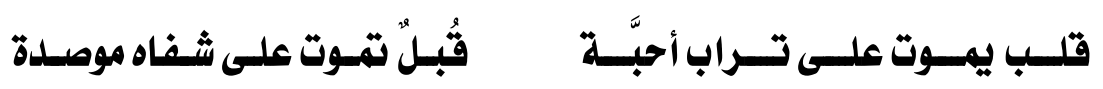




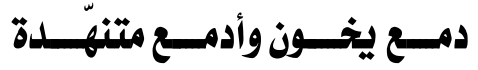

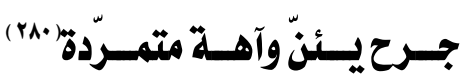

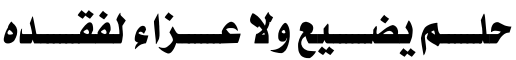

ظـلـ يسـير علـى السـدروب محطمَّا

قوله: (قلب) خبر والمبتدأ محذوف تقديره (حكاية العذاب الأولى).

وقوله: (قُبل) خبر والمبتدأ محذوف تقديره (حكاية العذاب الثاتية).

وقوله: (حلم) خبر والمبتدأ محذوف تقديره (حكاية العذاب الثالثة).

وقوله: (دمع) خبر والمبتدأ محذوف تقديره (حكاية العذاب الر ابعة).

وقوله: (أدمع) خبر والمبتدأ محذوف تقديره (حكاية العذاب الخامسة).

وقوله: (ظل) خبر والمبتدأ محذوف تقديره (حكاية (لعذاب السادسة).

وقوله: (جرح) خبر والمبتدأ محذوف ثقديره (حكاية العذاب السابعة).

وقوله: (آهةٌ) خبر والمبتدأ محذوف تقديره (حكاية العذاب الثامنة).

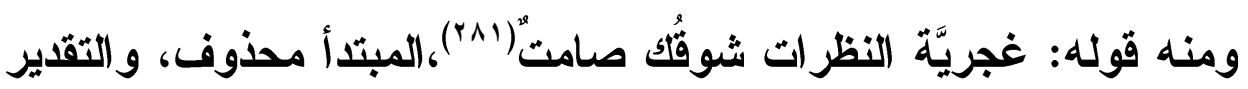

(أنتِ) غجرية النظر ات.

ومنه قوله :

ومشهـد الهوداعوالهمحار(r/r).

وزاده الرحيل يـا حبيبيتي

فالمبتدأ محذوف، والتقدير: (وزاده مشهدُ الوداع).

حذف الخبر:

لحذف الخبر وجهان، كما ذكر النحاة، حذف واجب، وحذف جائز. 


\section{يمذف الخبر وجوباً في هواضع أشهرها:}

- أن يكون الخبر كونًا مطلقًا، والمبتدأ بعد (لولا) الامتناعية. - أن يكون المبتدأ صريحًا في القسم.

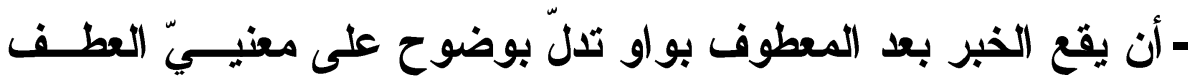

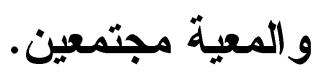
- قبل حال إن كان المبتدأ أو معموله مصدرًا عاملًا في مفسر صـاحبها

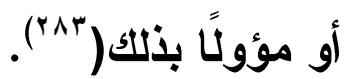

ولم يرد الخبر محذوفًا وجويًا في ديوان فينيق الجراح.

حذف الخبر جوازًا:

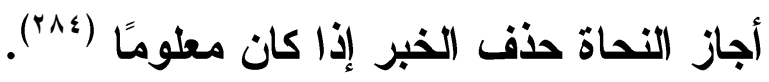

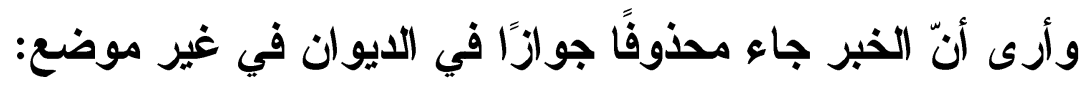

الأول: آهٍ من الآلام

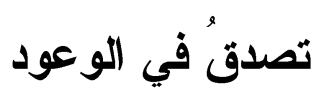

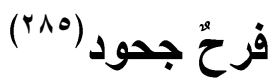

فقوله (فرحُ) مبتدأ وهي نكرة موصوفة بـ (جحسود)، حـذف الخبـر

وتقديره (يصدق) أو (مؤلم).

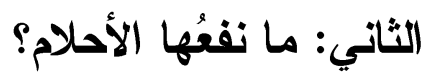

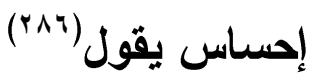

فقوله: (إحساس) مبتدأ و الخبر محذوف تقديره (هناك).

الثالث: وأسى بلا وجه يمزقّني

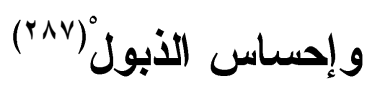




$$
\begin{aligned}
& \text { فـ (إحساس) مبتدأ والخبر تقديره (يمزّقَي). }
\end{aligned}
$$

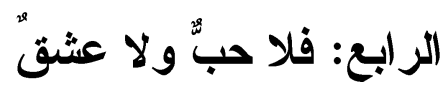

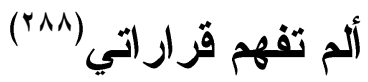

$$
\begin{aligned}
& \text { فــ(حبُّ) و(عثق) مبتدأ، والخبر محذوف تقديره (موجود). }
\end{aligned}
$$

ويتضح بتشغيل علامات الترقيم الاتلة على غياب المنطوق اللغـوي، ويظهر بوضوح في توظيف النقط الثثلاث(و^). وفي سباق التأثير في المتلقي

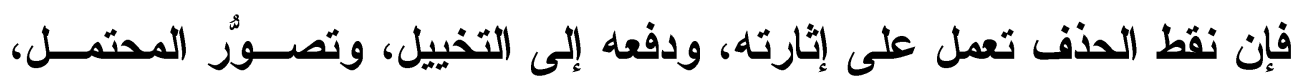
و البحث عن الجواب الصحيح(.9"r).

وقد ظهر الحذف الالالي في الجملة الاسمية في ديوان فينيق الجــراح في موضعين:

$$
\text { أولًاً: والأمس يرجع والرؤى ... حتى الرعود }
$$

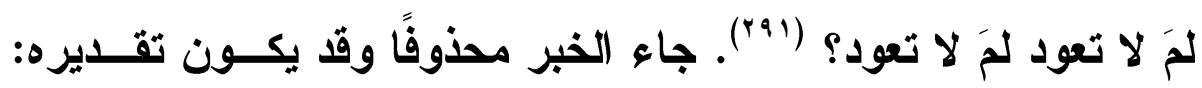

$$
\text { (ترجع) أو (تعود). }
$$

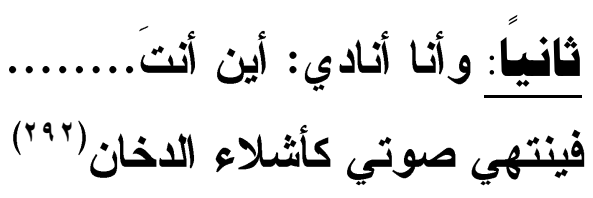

وقد يكون المحذوف هنا جملة اسمية، تقديرها (أين أنــــ)؛ ، تكـــرارًا

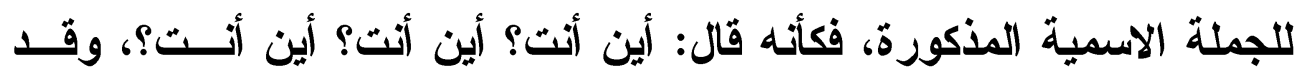
يكون المحذوف اسم الاستفهام (أين)، أو (أنت)، وكلها تقدير ات للمحــذوف يحتملها المعنى. 
بناء الجملة النحوية (الاسمية الخبرية) في ديوان

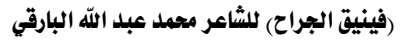

أوثًا: جاءت أنماط الجملة الاسمية الخبرية في ديوان (فينيق الجــراح)

على النحو الآتي:

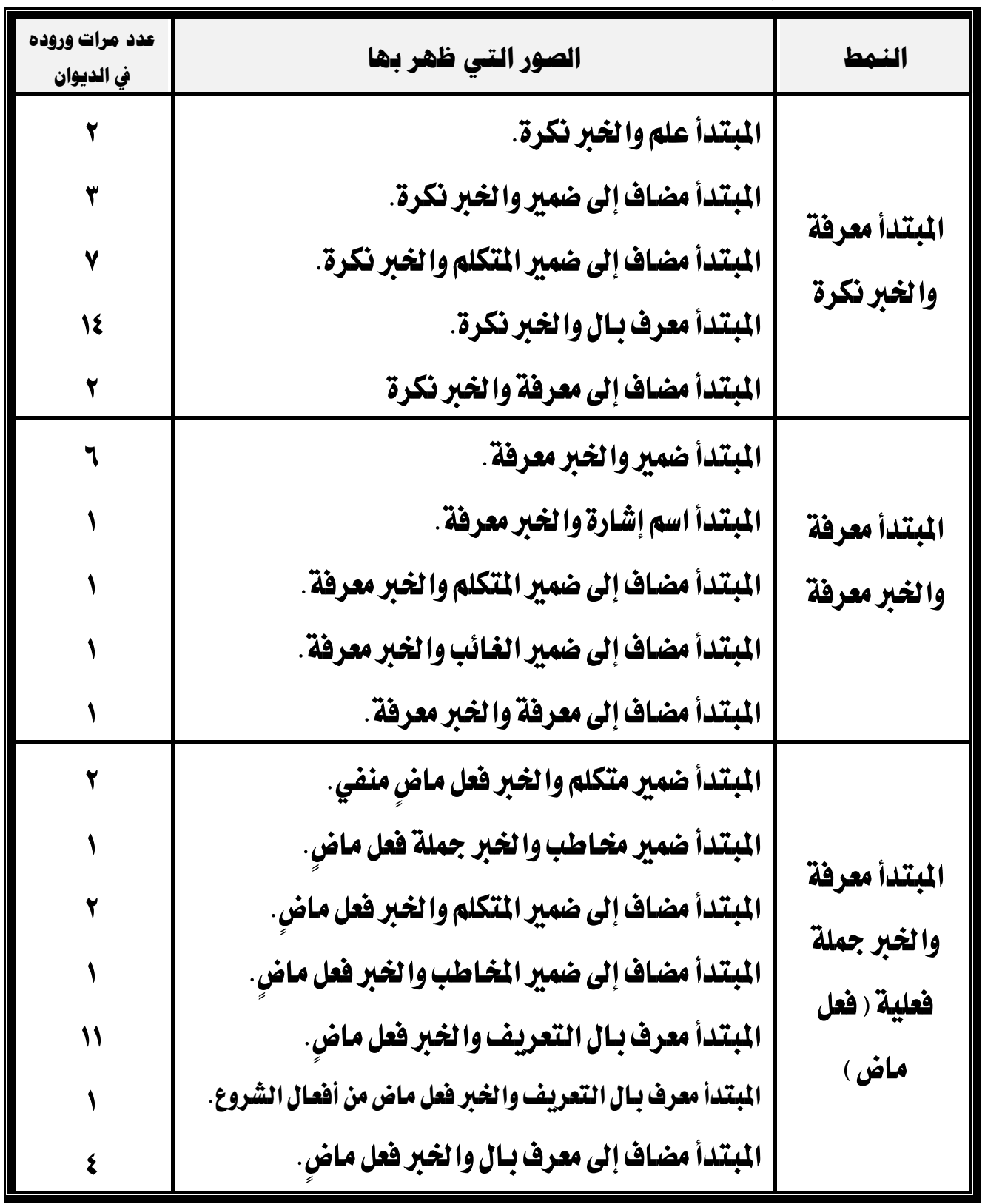

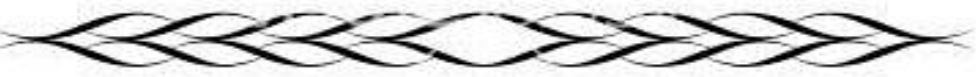


الترقير الدولي 2356-9050

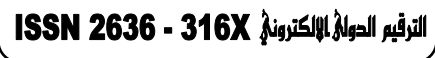

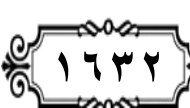

حولية كلية اللفة العربية بجرجا مجلة علمية محكمة الية المرلة

\begin{tabular}{|c|c|c|}
\hline عدد هرات وروده & الصور التي ظهر بها & النهط \\
\hline 1 & المبتدلأ ضمير المتكلم وا لخبر فعل مضارع. & \multirow{11}{*}{ فالمبتدأ معرفة } \\
\hline 0 & المبتدأ ضمير المخاطب وا لخبر فعل مضارع. & \\
\hline 9 & المبتدأ مضاف إلى ضمير المتكلم وا لخبر فعل مضارع. & \\
\hline r & المبتدأ مضاف إلى ضمير المخاطب والخبر فعل مضارع. & \\
\hline r & المبتلدأ مضاف إلى ضمير الفائب والخبر ففل مضارع. & \\
\hline 19 & المبتدأ معرف بـال التعريف والخبر فعل مضارع. & \\
\hline 1 & المبتلدأ معرفة بـإضافته إلى معرف بـالإضـافة إلى الضمير & \\
\hline$\varepsilon$ & والخبر جملة فملية. & \\
\hline \multirow[t]{3}{*}{$\varepsilon$} & المبتدأ معرفة بـالإضافة إلى معرف بـال التعريـف والخـبر & \\
\hline & فعل مضارع. & \\
\hline & المبتدأ معرفة والخبر بحلة فلية فعلها ناسخ. & \\
\hline$\xi$ & صالمبتلأ معرفة والخبر جملة فلية فملها ناسخ، ( ليس، & فلملية فلملدأ معرفة \\
\hline 1 & المبتدأ اسم إشارة والخبر جملة اسمية. & المبتدأ معرفة والخبر \\
\hline 1 & المبتلدأ معرف بـال والخبر جملة اسمية. & 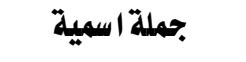 \\
\hline 1 & المبتلأ معرف بال والخبر شبه جملة ( ظرف ). & المبتدأ معرفة \\
\hline 1 & المبتدأ معرف بال والخبر شبه جملة ( جارومجرور ). & والخبر شبه جملة \\
\hline
\end{tabular}




\begin{tabular}{|c|c|c|}
\hline 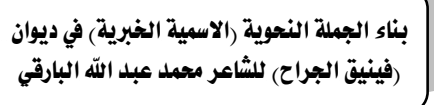 & | بناء الجبلة النحوية (الآر & العدد الرابع والعشرون للعام •r.r. الجزء الثاني \\
\hline عد في الديوات وروده & الصور التي ظهر بها & النهط \\
\hline r & المبتلأ نكرة محضة والخبر نكرة محضة. & \\
\hline r & المبتدأ نكرة موصوفة والخبر جملة فعلية. & \\
\hline 1 & المبتدأ نكرة مقيلدة بشبه جملة وا لخبر جملة فملية. & \\
\hline 1 & المبتــلأ نكـرة مقيـلدة بشبـه جملـة والخـبر جملـة فمليـلة & \\
\hline 1 & 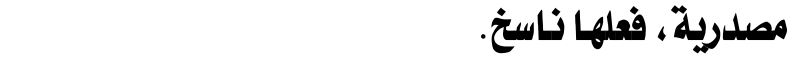 & \\
\hline$\checkmark$ & المبتدأ نكرة معطوف عليها وا لخبر جملة فملية. & \\
\hline & المبتدأ نكرة محضة والخبر جملة فعلية. & \\
\hline 0 & الخبر شبه جملة والمبتدأ نكرة. & تقدليم الخبر علىً \\
\hline r & الخبر شبه جملة والمبتدأ نكرة موصوفة. & \\
\hline r & الخبر شبه جملة والمبتدأ معرفة. & (ئ日) \\
\hline 1 & الخبر معرفة والمبتلأ معرفة. & \\
\hline r & ( إنّ ) وا سمها ضمير متكلم وخبرهـا نكرة. & 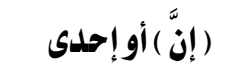 \\
\hline r & ( ) إذ ) واسمها معرف بـال والخبر نكرة. & 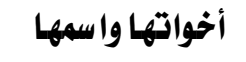 \\
\hline 1 & ( لكزّ ) وا سمها معرف بـالإضافة إلى الضمير والخبر نكرة. & معرفة والخبر نكرة \\
\hline r & ( أذَّ ) وا سمها ضمير متكلم والخبر معرفة. & 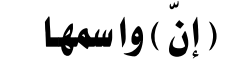 \\
\hline 1 & ( كانَّ ) وا سمها ضمير غائب والخبر معرفة. & معرفة وخبرها \\
\hline 1 & ( أز ) وا سمها مضاف إلى الضمير والخبر معرفة. & معرفة \\
\hline 1 & ( إن ) وا سمها معرفة مضاف إلى ضمير المتكلم وا لخبر فمل & 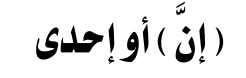 \\
\hline 0 & 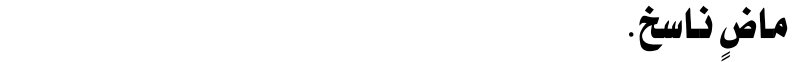 & أخواتها وا سههـا \\
\hline 1 & ( إذ ) أو إحدى أخواتها وا سمها معرفة معرف بـال والخبر & معرفة وخبرها \\
\hline
\end{tabular}




\begin{tabular}{|c|c|c|}
\hline 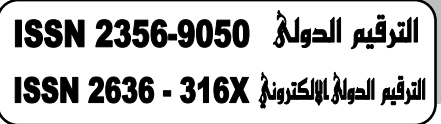 & 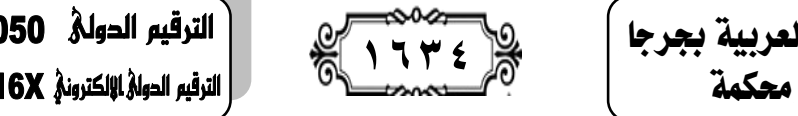 & حولية كلية اللفة العربية بجرجة مجلية \\
\hline عد هرات فردوات & الصور التي ظهر بها & 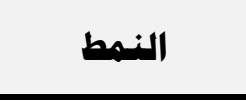 \\
\hline 1 & 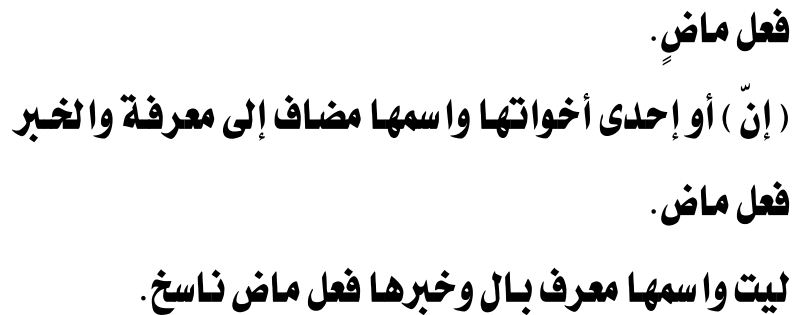 & فمل ماض \\
\hline$\varepsilon$ & (المتكلم ) أو إحلى أخواتها وا سههـا معرفة مضـاف إلى ضمير & ( إنّ ) أو إحدى \\
\hline 1 & ( لعلّ ) وا سهها ضمير المتكله وا لخبر فعل مضارع. & أخواتها والخبر \\
\hline 1 & ( لكزّ" )وا سمها ضمير الغائب وا الخبر فمل مضارع. & ( فمل مضارع ) \\
\hline$r$ & ( إنّ ) أو إحدى أخواتها وا سمها معرف بـال والخبر فعل مضارع. & \\
\hline 1 & ( لكزّ ) وا سمها ضمير المتكلم وخبرها ناسخ. & ( إنّ) أو إحدى \\
\hline 0 & ( ليت ) وا سمها ضمير المخاطب وخبرها ناسخ. & أخواتها وا سمها \\
\hline 1 & ( أنّ ) وا سمها معرفة بـالإضافة إلى معرف ب( ال ) وخبرها ناسخ. & معرفة وخبرهـا ناسخ \\
\hline 1 & اسم ( إنّ ) نكرة وخبرها شبه جملة. & أو إحلدى أخواتها خبرا إنّا \\
\hline 7 & لا النافية للجنس وا سمها نكرة وخبرها فعل مضارع. & ل الالنافية \\
\hline 1 & لا النـافية للجنس وا سمها نكرة وخبرها نكرة. & 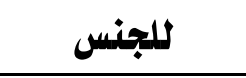 \\
\hline
\end{tabular}




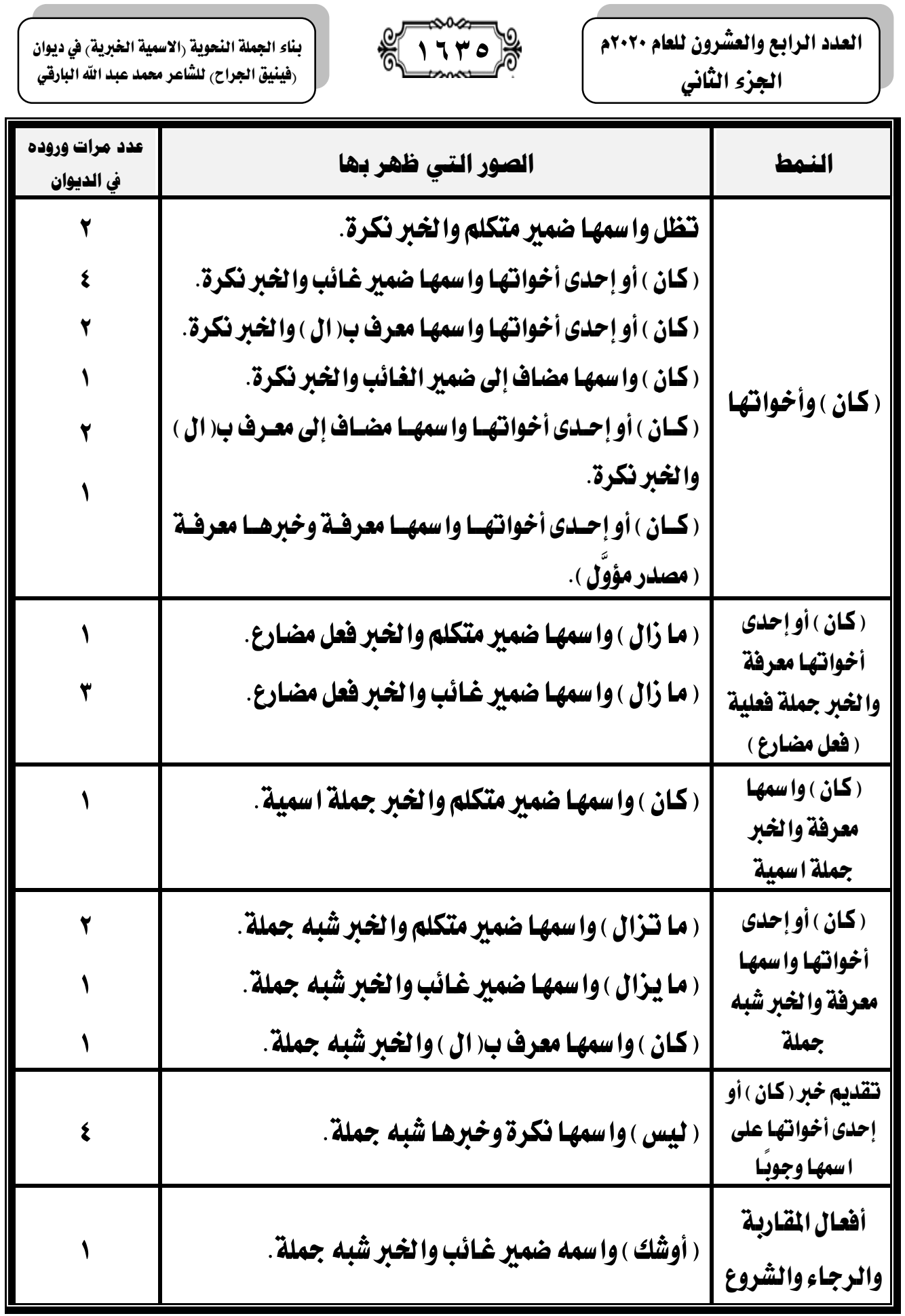


ثانياً: لم يخرج الثـاعر محمــــ البارقي في ديوانه عن أنماط الجمــــة

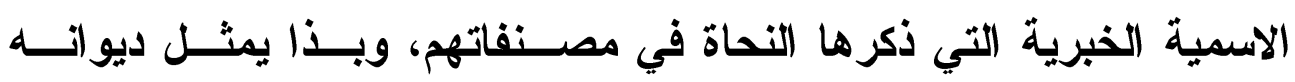

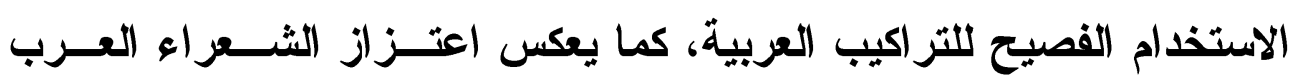

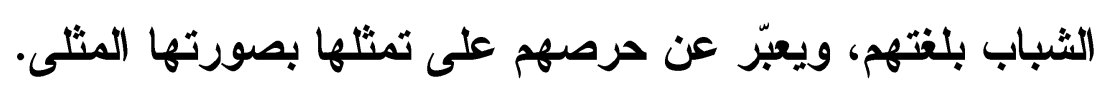

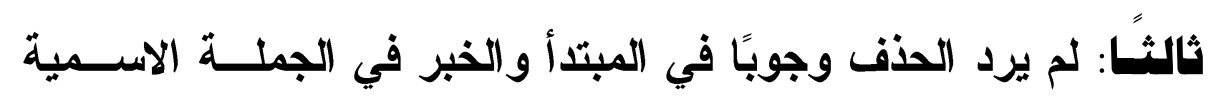

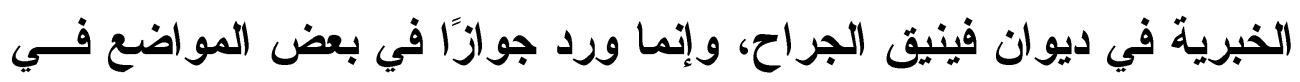

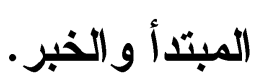

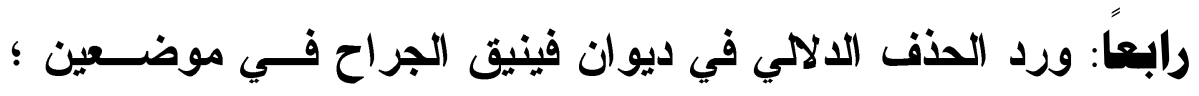
ويظهر ذلك بوضوح في توظيف النقط الثُلاث، ومن ذلك قوله: والأمس يرجع و الرؤى ... حتى الرعود

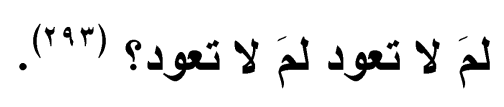$$
\text { جاء الخبر محذوفًا وقد يكون تقديره: (ترجع) أو (تعود). }
$$

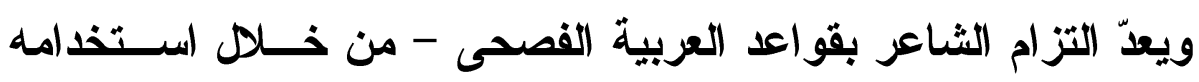

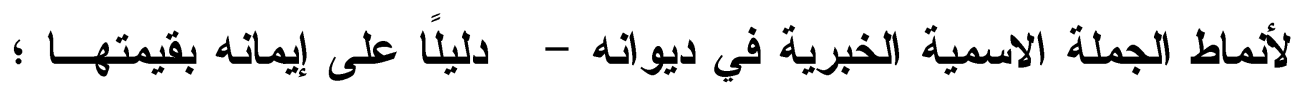

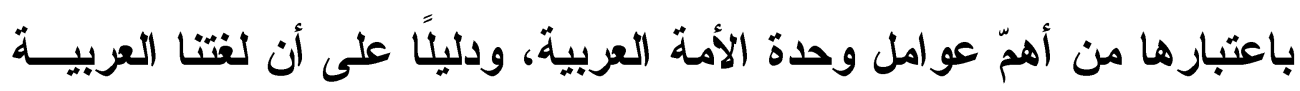

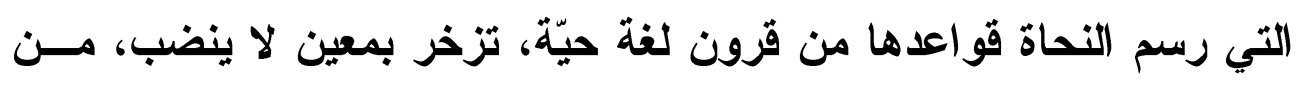

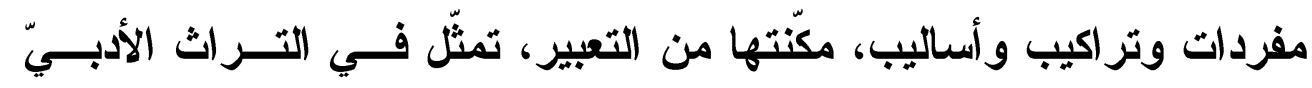

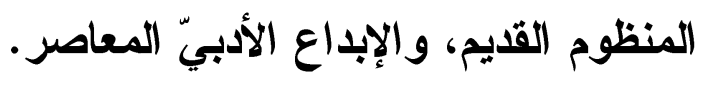




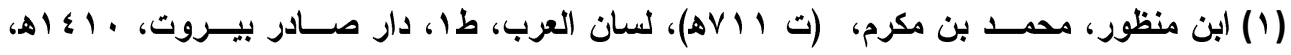

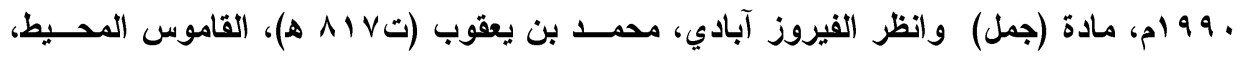

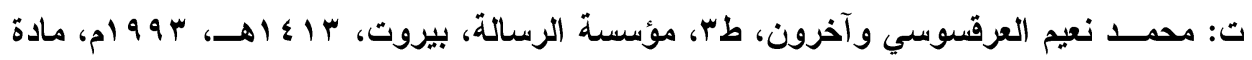

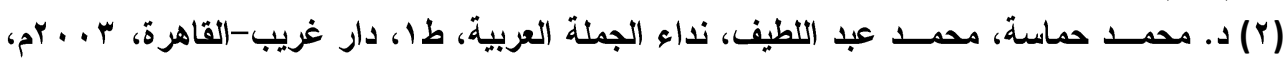
טו

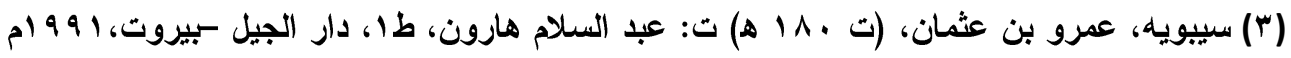

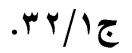

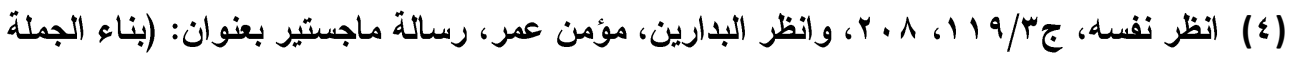

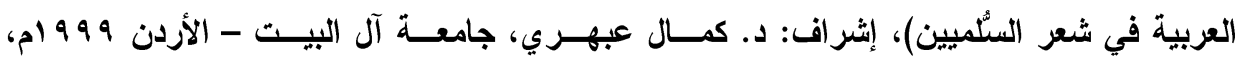
ص.

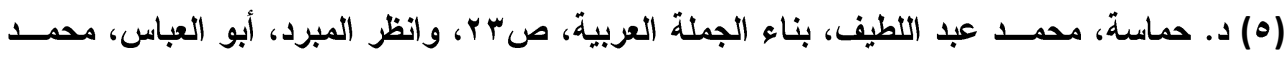

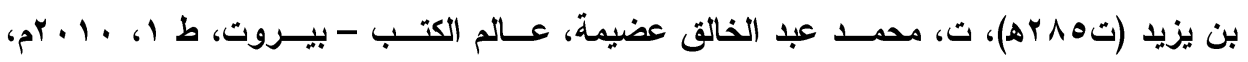

$$
\begin{aligned}
& \text { ج جن/ }
\end{aligned}
$$

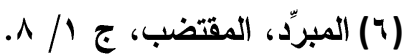

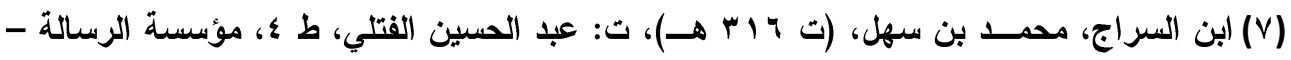

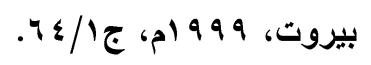

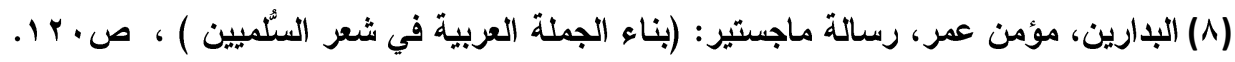

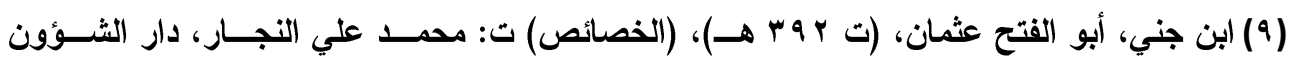

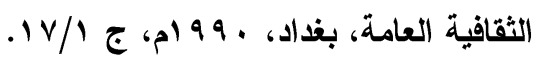

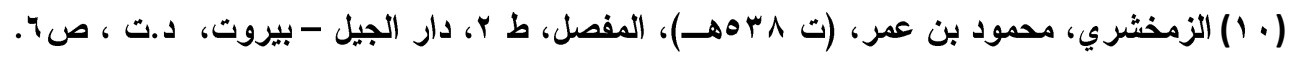

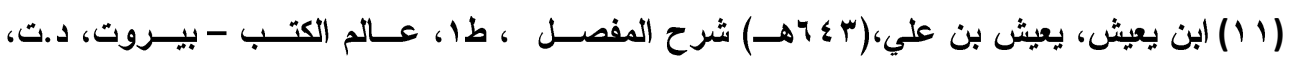

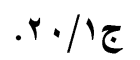

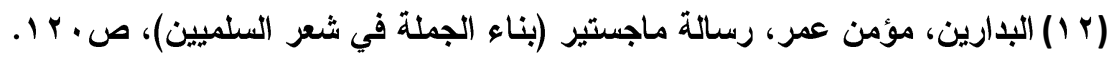

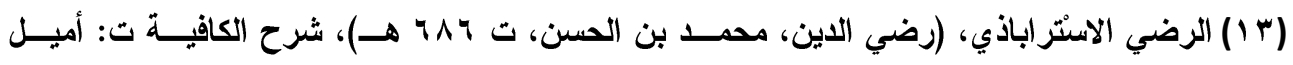

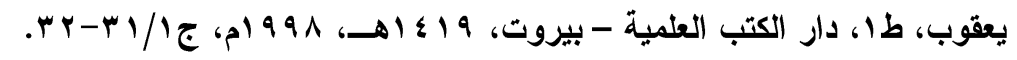

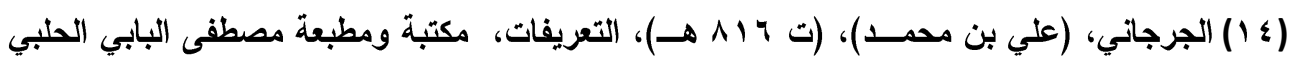

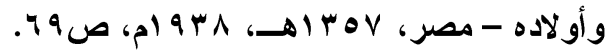

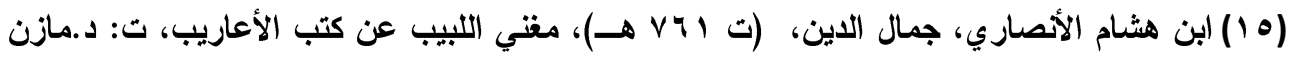

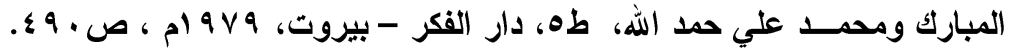

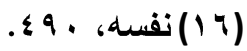

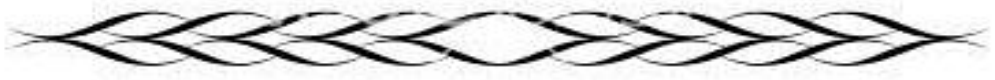


(انظر الزهوي ، رشيد محمـد، رسالة ماجستير بعنوان (الجملة الاسمية عند النحويين حتى نهاية

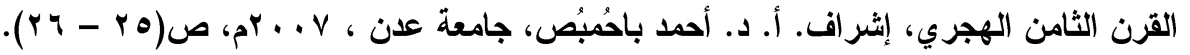

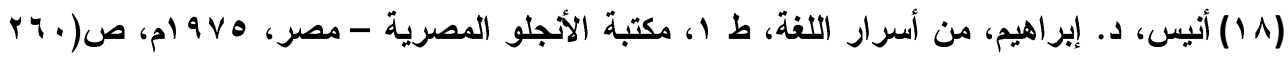

$$
\cdot(r)-
$$

(9 1) المخزومي، د. مهدي، في النحو العربي نقد وتوجيه، ط ا، منشورات المكتبة العصرية - بيزوت،

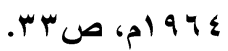

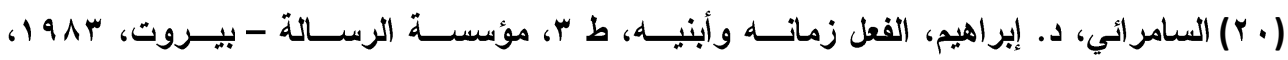

$$
\text { ص(1) }
$$

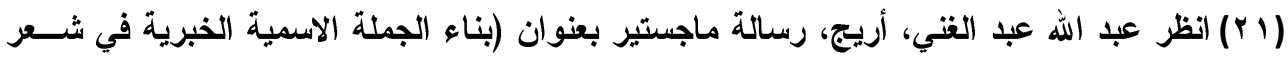

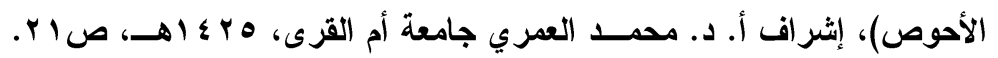

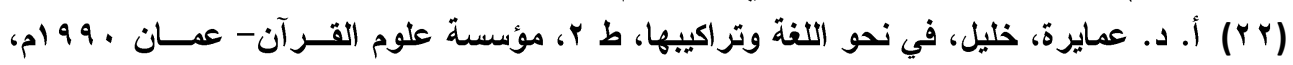

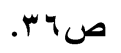

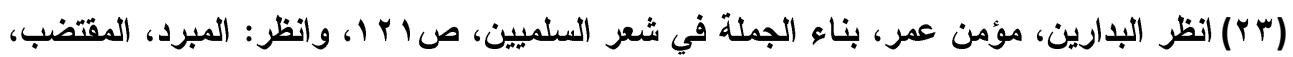

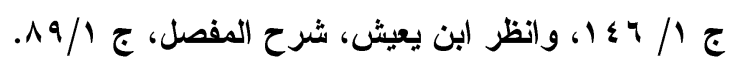

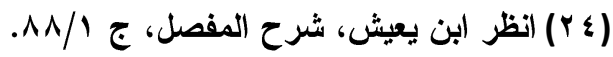

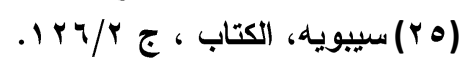

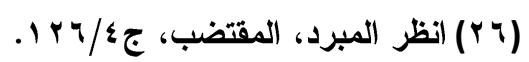

(rV)

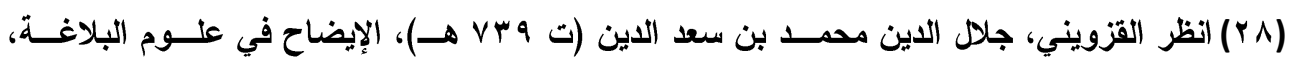

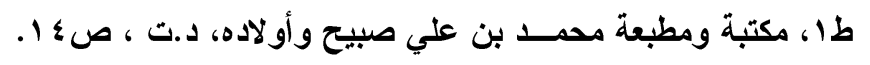

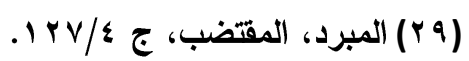

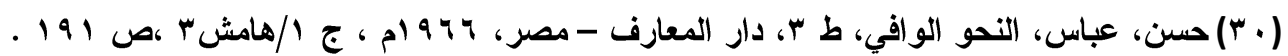

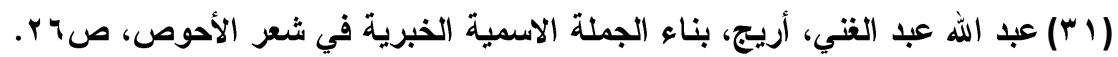

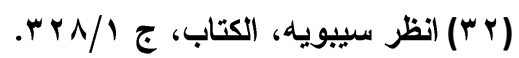

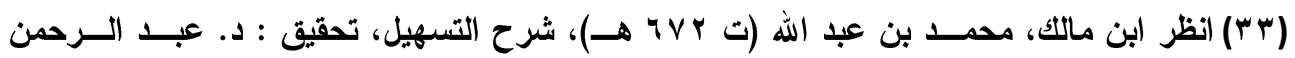

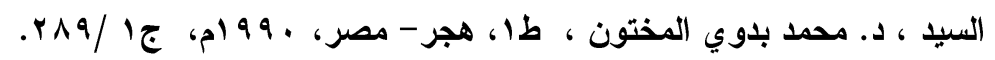

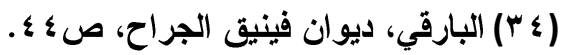

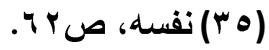

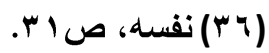

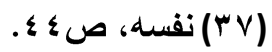

(r ) نفسه، ص

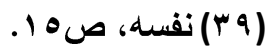

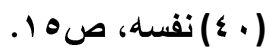



الجزء الثاني

$$
\begin{aligned}
& \text { (1) (1) نفسه، ص ابr. } \\
& \text { ( ) }
\end{aligned}
$$

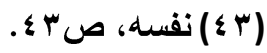

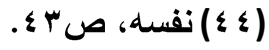

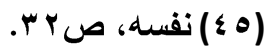

$$
\begin{aligned}
& \text { (Y) }
\end{aligned}
$$

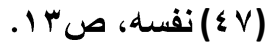

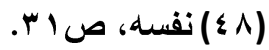

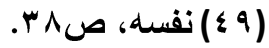

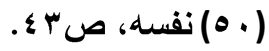

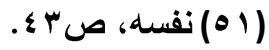

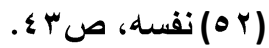

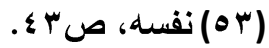

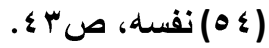

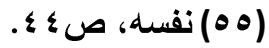

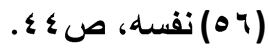

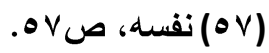

$$
\begin{aligned}
& \text { ) }
\end{aligned}
$$

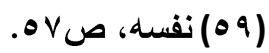

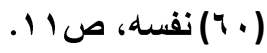

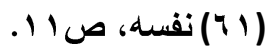



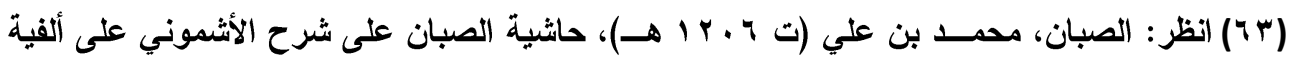

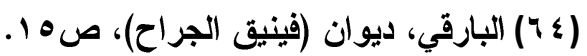

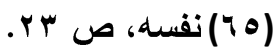

$$
\begin{aligned}
& \text { (ד) }
\end{aligned}
$$

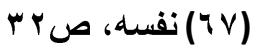

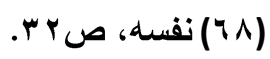

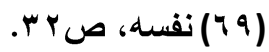

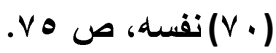

$$
\begin{aligned}
& \text { (VI) نفسه، ص } 99 . \\
& \text { (V) نفسه، ص هץ. (VY) }
\end{aligned}
$$

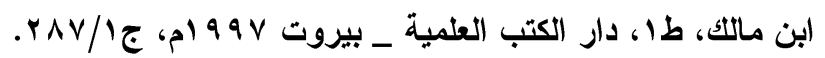




$$
\begin{aligned}
& \text { (VT) نفسه، صYVT) }
\end{aligned}
$$

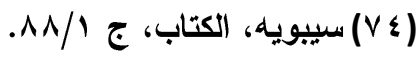

$$
\begin{aligned}
& \text { سورة الحاقة: } 1 \text { - r. (V) }
\end{aligned}
$$

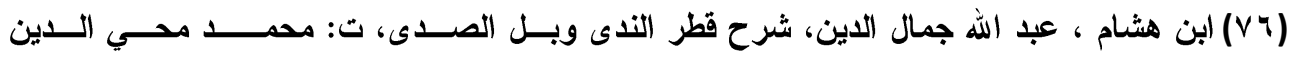

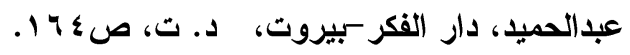

(VV)

$$
\text { (VA) }
$$

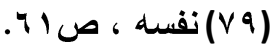

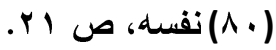

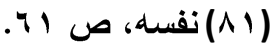

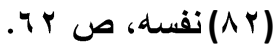

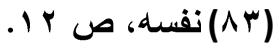

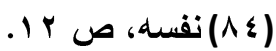

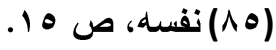$$
\text { ) }
$$

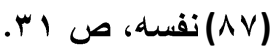$$
\text { (A^) }
$$

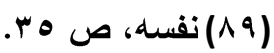

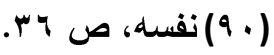

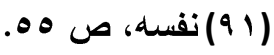

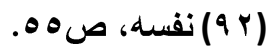

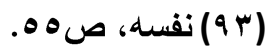

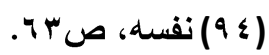

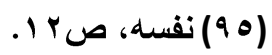

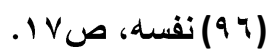

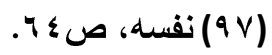

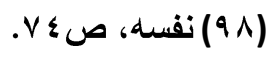

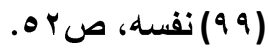

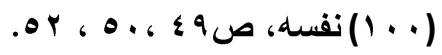

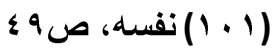

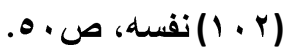

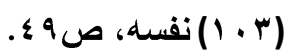

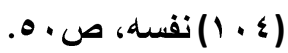




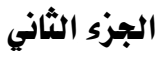

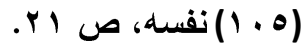

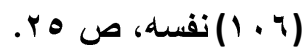

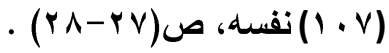

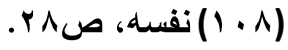

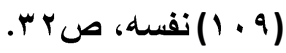

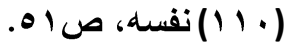

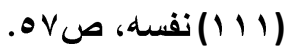

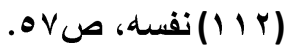

$$
\begin{aligned}
& \text { ( ) }
\end{aligned}
$$

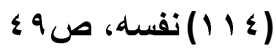

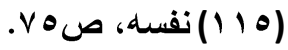

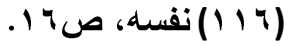

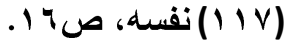

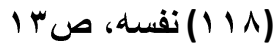

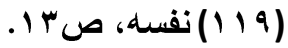

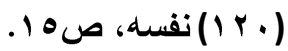

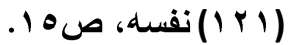

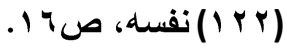

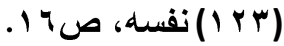

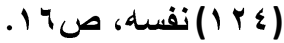

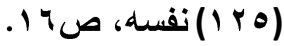

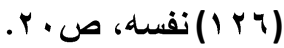

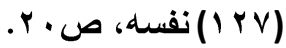

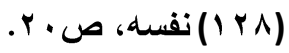

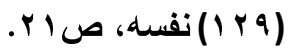

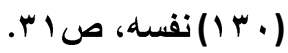

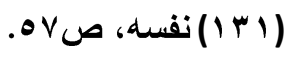

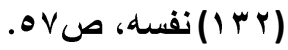

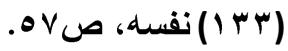

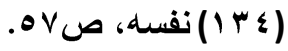

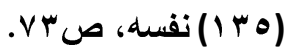

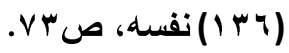

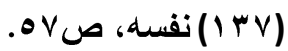




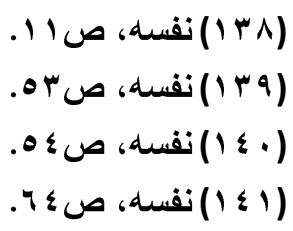

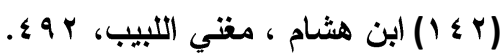

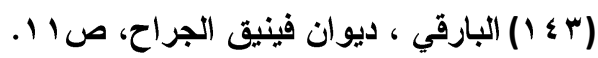

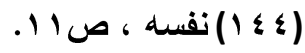

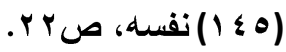

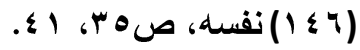

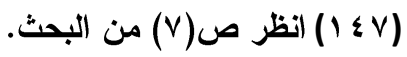

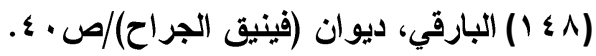

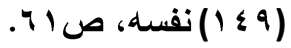

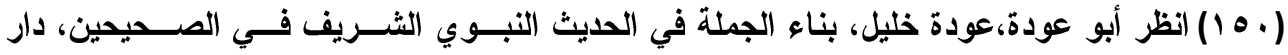

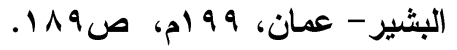

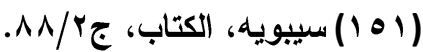

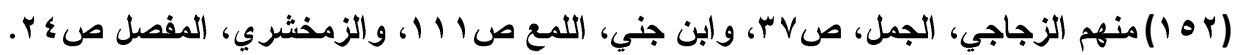

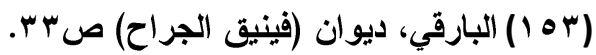

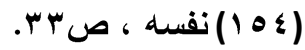$$
\text { (100) }
$$$$
\text { (107) }
$$

(lov)

(101) (101) (109)

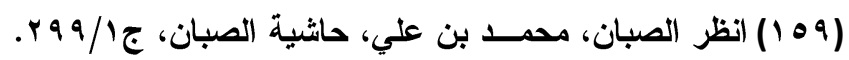

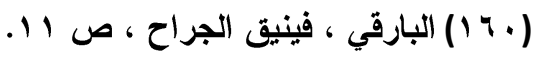

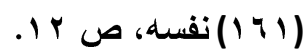

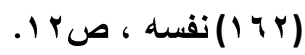

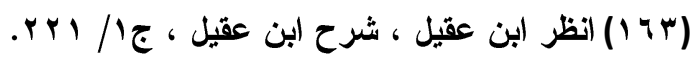

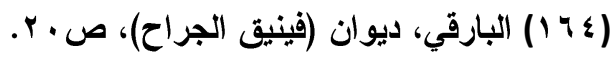

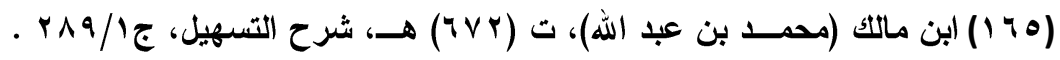

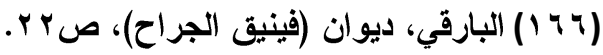

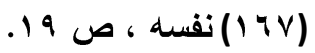

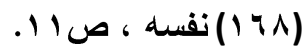

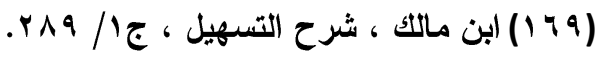




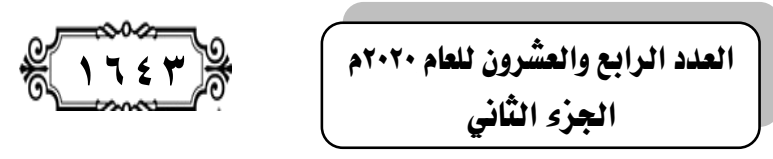

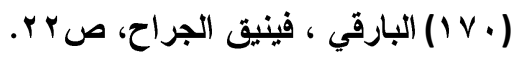

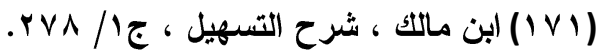

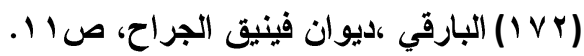

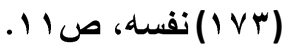

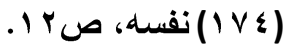

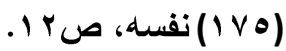

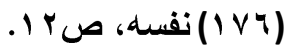

$$
\begin{aligned}
& \text { (IVV) } \\
& \text { (IVN) }
\end{aligned}
$$

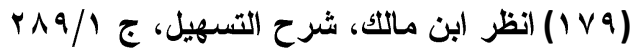

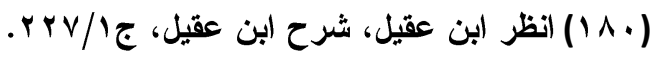

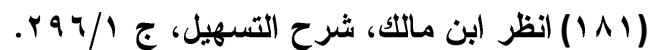

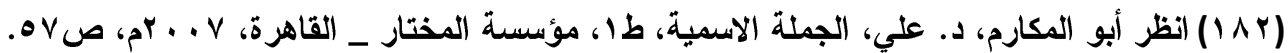

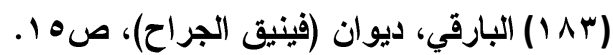

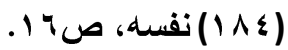

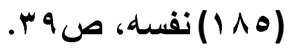

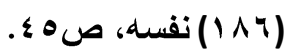
(INV)

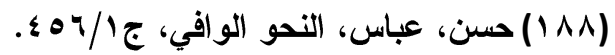

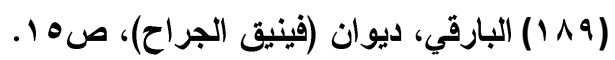

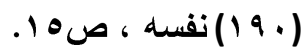

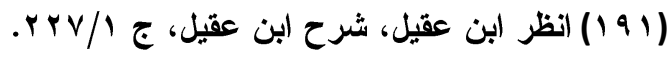

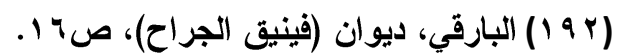

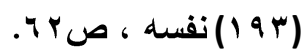

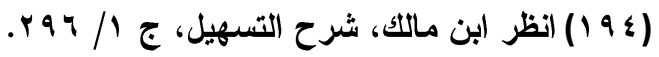

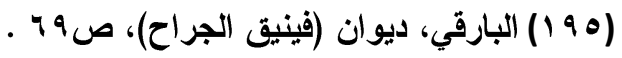

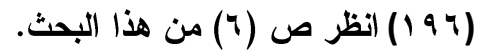

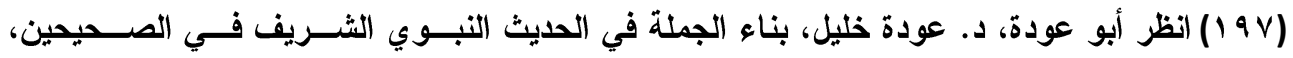
صמr

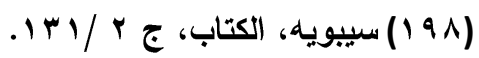

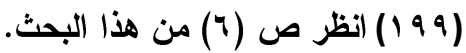

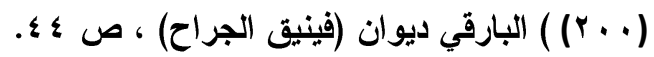

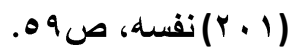




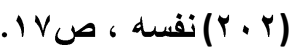

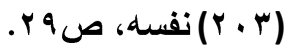

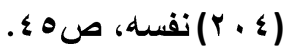

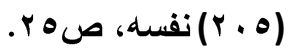

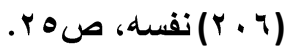

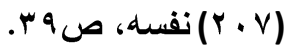

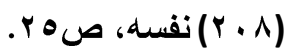

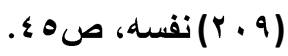

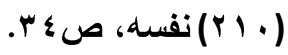

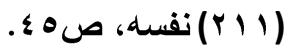

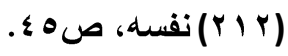

$$
\begin{aligned}
& \text { (Y) }
\end{aligned}
$$

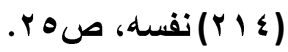

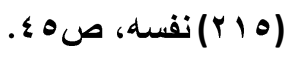

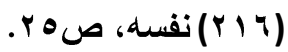

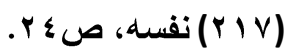

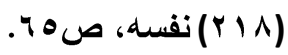

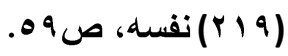

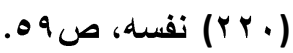

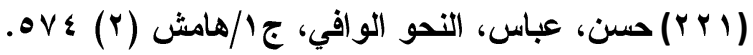

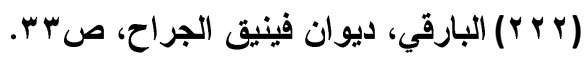

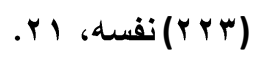

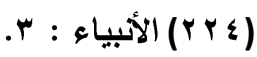

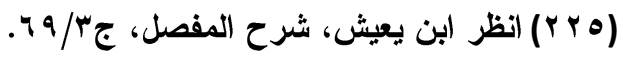

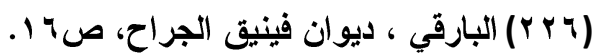

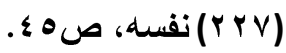

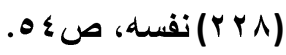

(Y) (YYq)

(Y)

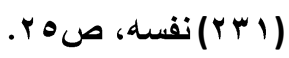

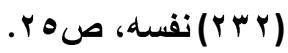

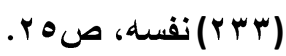

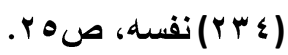




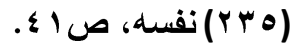

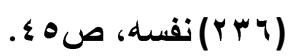

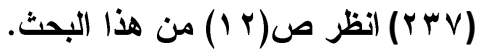

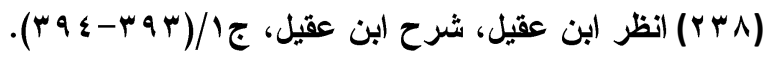

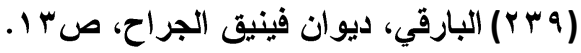

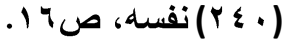

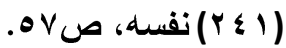

$$
\begin{aligned}
& \text {. }
\end{aligned}
$$

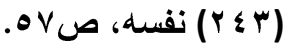

$$
\begin{aligned}
& \text { ( }
\end{aligned}
$$

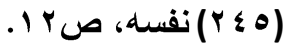

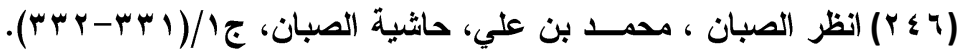

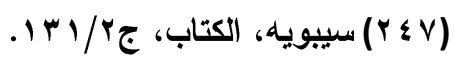

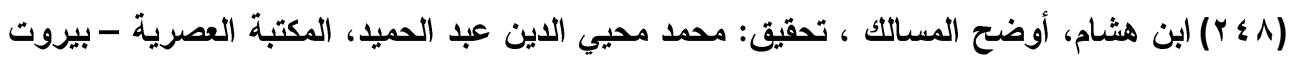

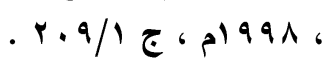

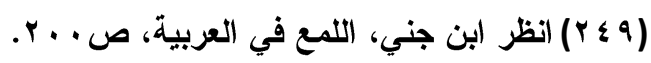

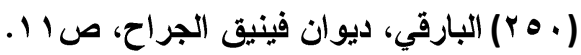

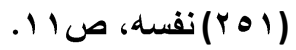

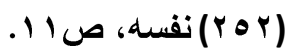

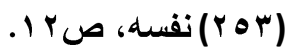

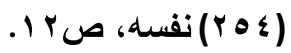

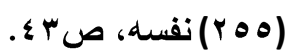

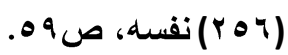

( نفسه، صوهV)

( نفسه، صا (Y०人)

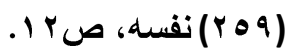

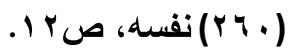

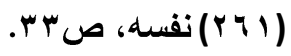

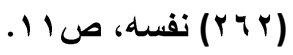

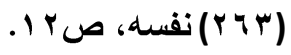

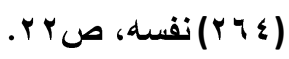

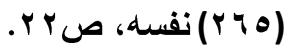

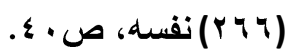




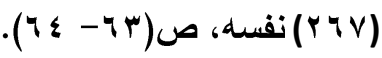

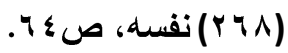

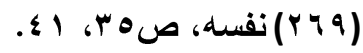

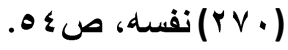

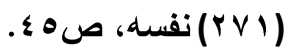

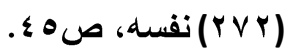

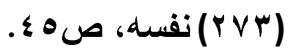

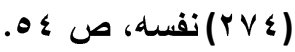

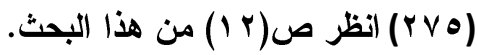

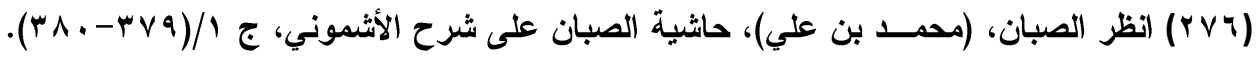
(YVV)

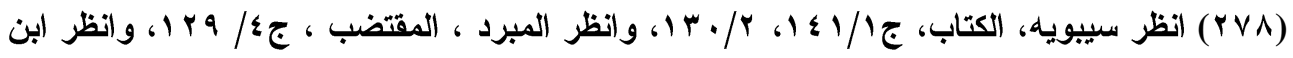

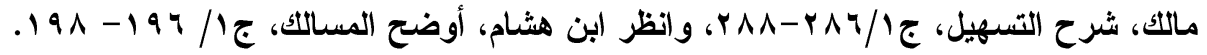

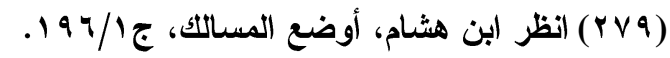

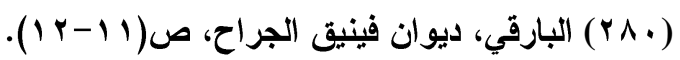

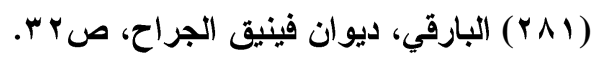

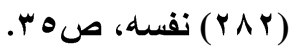

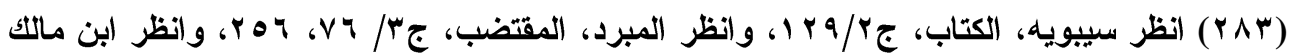

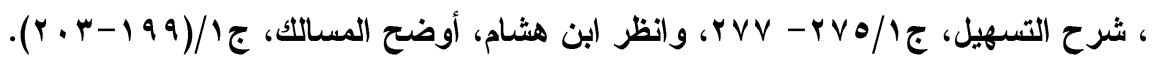

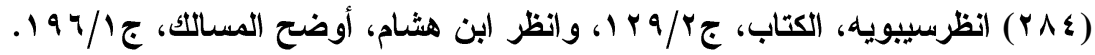

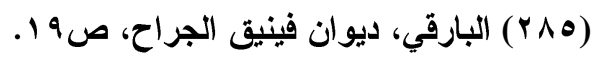

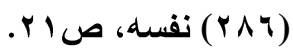

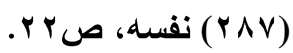
(YA^)

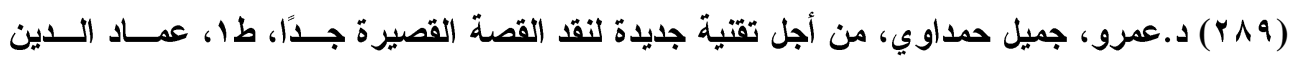

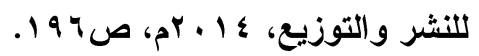

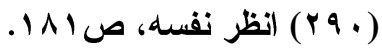

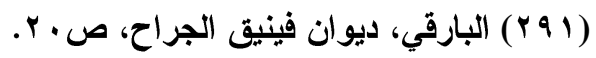
(r)

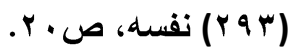


r- أنيس، د. إبراهيم، من أسرار اللغة، طا، مكتبة الأنجلــو المصـرية، مصــر،

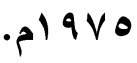

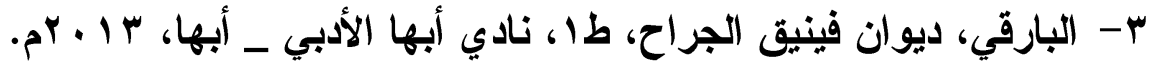

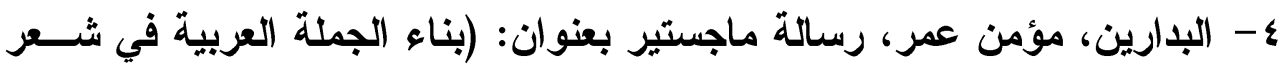

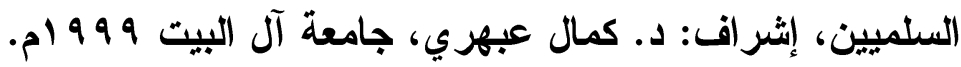

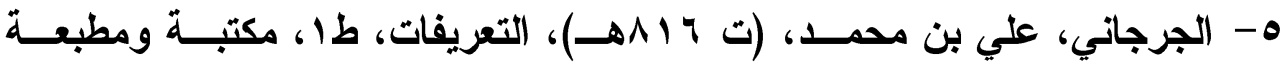

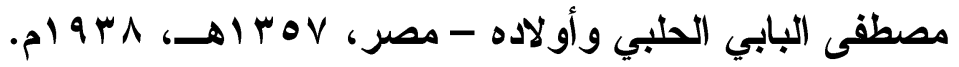

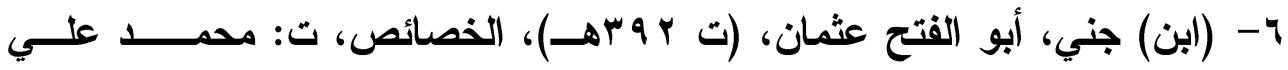

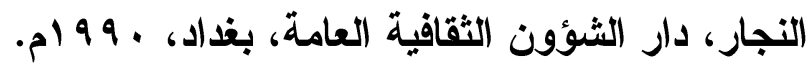

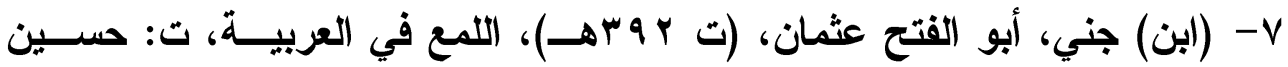

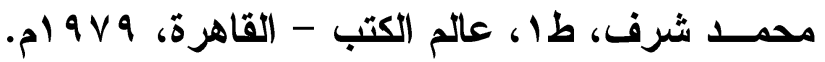

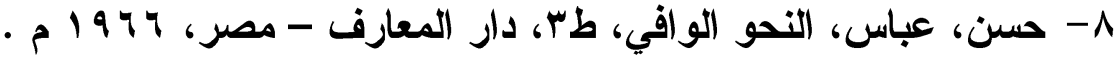

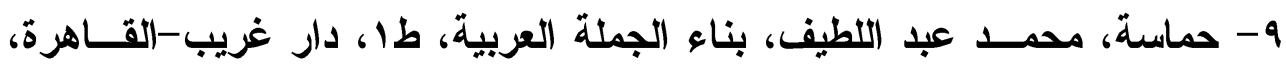
$\cdot r^{r} \cdot r$

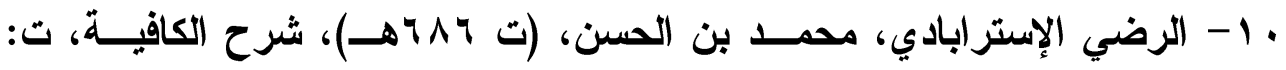

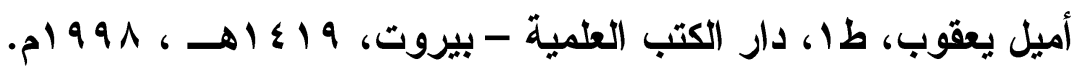

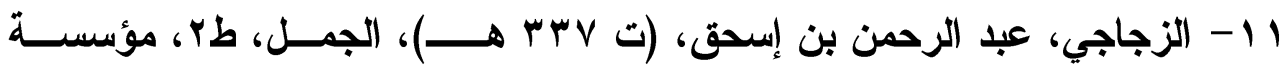

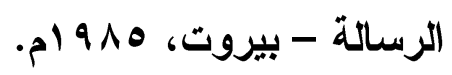

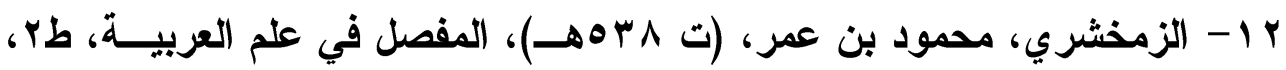

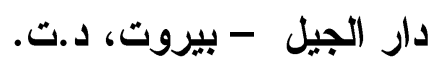

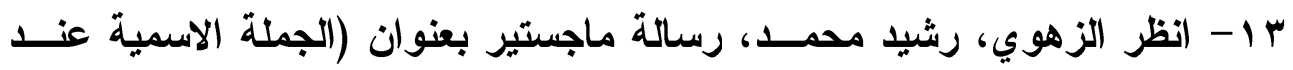

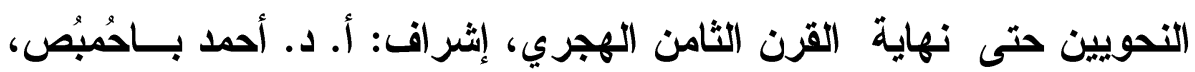

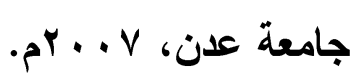


ع ا - السامرائي، د. إبراهيم، الفعل زمانه وأبنيته، طس، مؤسسة الرسالة - بيروت،

$$
\text { - } 9 \text { ) }
$$

ه 1 - (ابن) السراج، محمــد بن سهل، (ت 7 آسهـ)، ت: عبد الحسين الفتلي، ط؛،

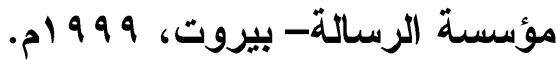
7 ا - سييويه، عمرو بن عثمان، (ت ، 1 اهـ)، ت :عبد السلام هـــارون، طا، دار

$$
\text { الجيل - بيزوت المو } 99 \text { ام. }
$$

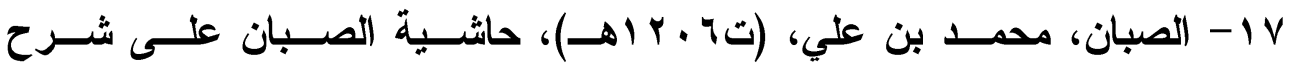

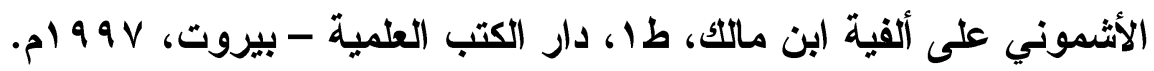

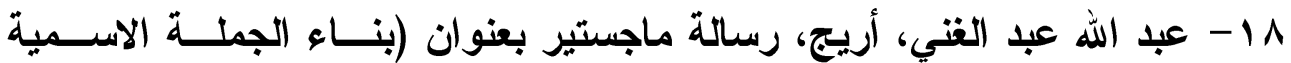

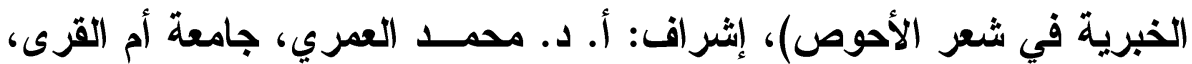
$\rightarrow 1 \leqslant$ Y O 9 ا - (ابن) عقيل، عبد الله، (ت VI 9 (ته)، شرح ابن عقيل على ألفية ابن مالكك، ت: محمـــ محيي الدين عبد الحميد، طץ، د.ن، د.ت.

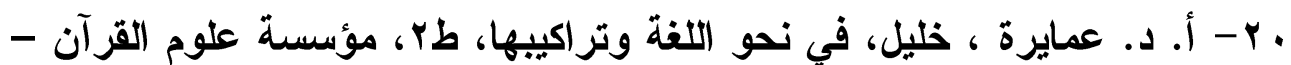

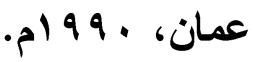
اץ- د. عمرو · جميل حماوي ، من أجل تقنية جديدة لنقد القصة القصيرة جدًا ،

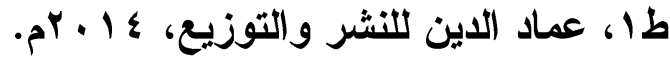

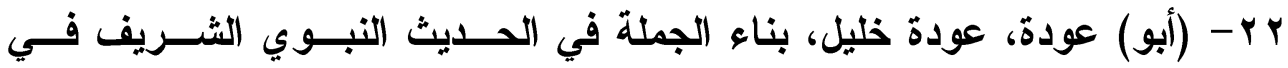

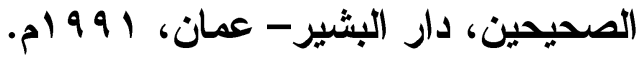

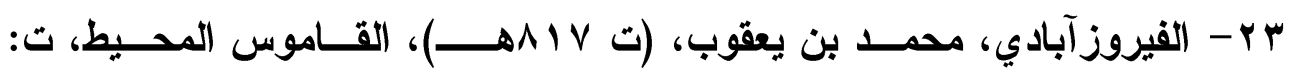

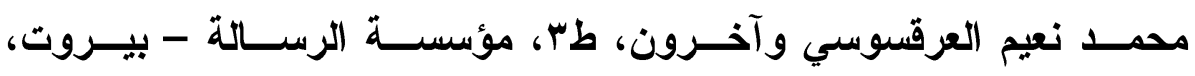

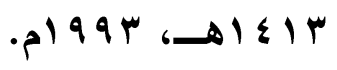

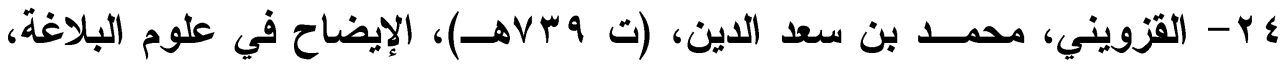
طا، مكتبة ومطبعة محمــد علي صبيح وأولاده. 


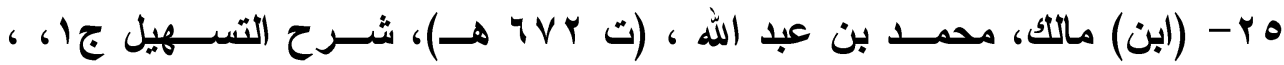

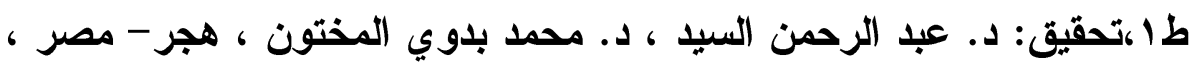
. 199 . צr- المبرد، محمــد بن يزيد، (ت هـr هــ)، المقتضب ، ت: محمــد عبد الخالق

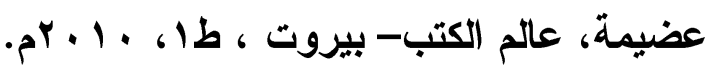
VV - المخزومي، د. مهدي، في النحو العربي نقل وتوجيــه، منشــورات المكتبــة

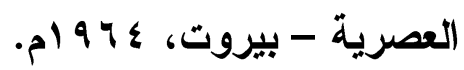
^ץ - (أبو) المكارم، د. علي، الجملة الاسمية، طال، مؤسسة المختــار - القــاهرة،

$$
\text { مr..v }
$$

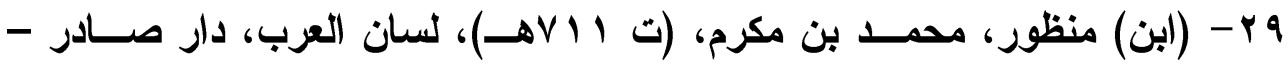

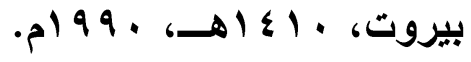

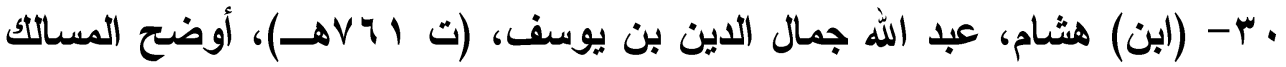
إلى ألفية ابن مالك، ت: محمد محيي الاين عبد الحميل ، طا، المكتبة العصرية

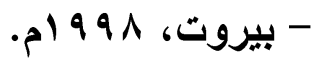

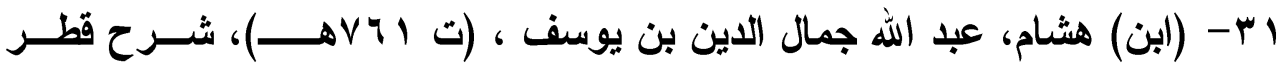

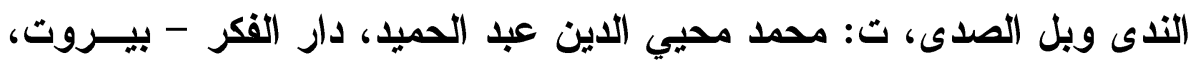

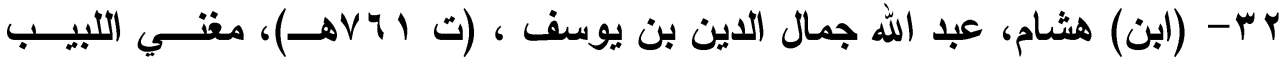

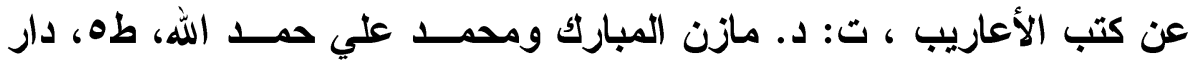

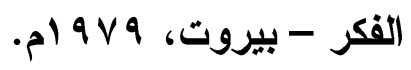

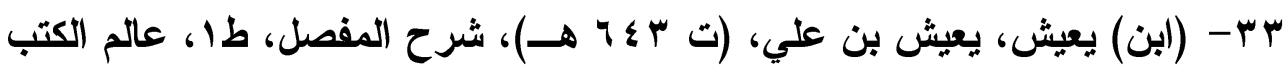

$$
\text { - بيروت، د.ت. }
$$


فهرس الموضوعات

\begin{tabular}{|c|c|c|}
\hline | الصفمة & 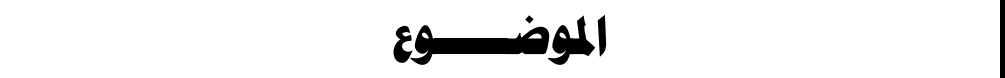 & p \\
\hline 1097 & هلذص البحث بالاغة العربية: & .1 \\
\hline $109 \mathrm{~V}$ & Abstract & $r$ \\
\hline 1091 & هُقدَ هَهَة: & $r$ \\
\hline $17 \ldots$ & الجملة في الاصطلاح عند النمويين القدهاء: & . \\
\hline $17 \cdot r$ & هفهوم البملة عند علمهاء النحو المحدثين: & .0 \\
\hline $17 \cdot \varepsilon$ & أقسام البملة العربية: & .7 \\
\hline 1717 & تقديم الخبر على المبتدأ & $\checkmark$ \\
\hline $174 V$ & حذف الجملة الاسمية &.$\wedge$ \\
\hline 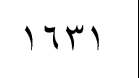 & خلاصة البصث & .9 \\
\hline 1748 & الهوا مشث & $1 \cdot$ \\
\hline $17 \leqslant V$ & 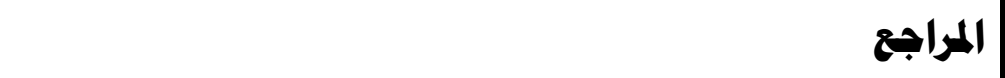 & 11 \\
\hline 170. & فهرس الموضوعات & ir \\
\hline
\end{tabular}

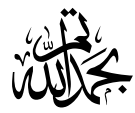

